\title{
Barriers to circular food supply chains in China
}

\author{
Citation: Muhammad Farooque, Abraham Zhang and Yanping Liu (2019). "Barriers to circular \\ food supply chains in China", Supply Chain Management: An International Journal. DOI: \\ https://doi.org/10.1108/SCM-10-2018-0345 \\ Muhammad Farooque \\ Business School, Auckland University of Technology, Auckland, New Zealand and \\ Department of Business Administration, Sukkur IBA University, Sukkur, Pakistan \\ Abraham Zhang \\ Business School, Auckland University of Technology, Auckland, New Zealand \\ Lumen Research Institute, Excelsia College and Indiana Wesleyan University, 69-71 Waterloo \\ Road, Macquarie Park, NSW 2113 Australia \\ Yanping Liu* \\ Department of Management Science and Engineering, Business School, Nankai University, \\ Tianjin, China
}

\begin{abstract}
Purpose: This paper aims to identify and systematically analyze the causal-effect relationships among barriers to circular food supply chains in China.

Design/methodology/approach: Grounded in multiple organizational theories, this paper develops a theoretical framework for identifying relevant barriers to integrating circular economy philosophy in food supply chain management. The study utilizes 105 responses from Chinese food supply chain stakeholders including food processors, sales and distribution channels, consumers and government officials. It applies a fuzzy Decision-Making Trial and Evaluation Laboratory (DEMATEL) method to examine the causal-effect relationships among the identified barriers.
\end{abstract}

Findings: Overall, the results suggest two key cause barriers, namely, weak environmental regulations and enforcement, and lack of market preference/pressure. Whereas, lack of collaboration/support from supply chain actors is the most prominent barrier. Key cause and prominent barriers for each of involved supply chain stakeholder are also identified.

Research implications: The study offers practical insights for overcoming barriers to integrating circular economy philosophy in the management of supply chains in the Chinese food sector, as well as in other contexts where similar challenges are faced. It also sheds light on which organizational theories are most suitable for guiding similar studies.

Originality/value: To the best of our knowledge, this is the first barrier study on circular food supply chains. The use of multiple organizational theories for the development of the theoretical framework is unique in barrier studies. The study offers insights from multiple stakeholders in the Chinese food supply chains.

Keywords: Sustainable supply chain; Circular supply chain; Food industry; Circular economy; Barrier; Fuzzy DEMATEL; China

Article Classification: Research paper 


\section{Introduction}

Food loss and waste throughout the supply chain is considered to be a significant contributor to the overall waste production (Borrello et al., 2016). It is estimated that about one-third of the world's edible food (approximately 1.3 billion tons) is lost or wasted throughout global food supply chains (FAO, 2011). Increasing food waste is thus becoming an issue for global food security and environmental governance, having significant environmental, economic, and social impacts (Stenmarck et al., 2016, Liu et al., 2013). According to Nature's recent special issue on circular economy (CE), China's consumption of the world's resources and the amount of waste generated pose a severe threat to the world's sustainability (Mathews and Tan, 2016). In 2014, China produced 3.2 billion tonnes of solid industrial waste, of which 1.2 billion tonnes (about 37.5\%) could not be recovered by any means (reuse, recycling/composting or incineration) and was therefore sent to landfills (Mathews and Tan, 2016). In China, about onesixth (35 million tonnes) of the total grain produced in China is wasted annually in the production, processing and transportation because of inadequate infrastructure, knowledge and technology, poor equipment and logistical issues that are exacerbated by a decentralized agricultural production system (Liu et al., 2013, Cui and Shoemaker, 2018).

Faced with these severe waste management and environmental challenges (Geng et al., 2013), the Chinese government has adopted various policies, legislation, and financial measures to strengthen its CE program (Mathews and Tan, 2016). CE is an industrial system based on restorative and regenerative design thinking, far more sustainable than the dominant linear economic model (make, use, dispose) (Stahel, 2016). In CE, outputs from one organization are turned into inputs for another through biological (natural decomposition) and technical (remanufacturing, refurbishing, and recycling) cycles, aiming to thereby generate no waste at all (EMF, 2013, EMF, 2014). Because of its promising vision, CE has been embraced not only 
by the Chinese government but also many other economies including the European Union, Japan, Australia and New Zealand.

From a supply chain perspective, CE has quickly become an influential driving force behind supply chain sustainability both in research and in practice (Genovese et al., 2017, Hobson, 2016, Nasir et al., 2017), offering a new and innovative sustainability frontier in supply chain management $(\mathrm{SCM})$. The integration of $\mathrm{CE}$ in the supply chain has been termed as circular supply chain in the extant literature (Genovese et al., 2017, Batista et al., 2018a, Farooque and Zhang, 2017). The $14^{\text {th }}$ annual global supply chain top 25 report for 2018 , published by Gartner, states that moving to circular supply chain is one of the most common trends among global supply chain leaders including Apple, Coca-Cola, HP Inc., Schneider Electric, Cisco Systems, Colgate-Palmolive, and BASF. This widely recognized Gartner report affirms that "the future of supply chain is circular, not linear" (Aronow et al., 2018).

Since making CE part of its national development policy in 2008, China has been investing billions of dollars in CE-oriented pilot projects. They range from cleaner production applications in specific sectors to the development of national and regional eco-industrial parks (EIPs) (Geng et al., 2013). However, linking firms by circular supply chains to cooperate in turning outputs into inputs (i.e., waste into resources) has been the main obstacle to successful implementation of CE (Mathews and Tan, 2016). The transition towards CE requires considerable transformations in supply chain practices related to design, production, consumption, waste management, reuse, and recycling (Hobson, 2016). There are also implications for logistics flows at all supply chain stages (Bicket et al., 2014). Thus, at a micro level (that of organizations' operations and supply chain), the integration of CE into SCM is the biggest hurdle in transforming China into a CE. 
Previous studies on the CE concept and implementation in China (Geng and Doberstein, 2008, Geng et al., 2009, Geng et al., 2012, Su et al., 2013) have broadly discussed some challenges/barriers at a macro level (that of regional economies). However, most of these conceptual studies offer a general perspective which might not be fully applicable in the supply chain (micro level) context. Among the few studies on CE with a supply chain perspective, Govindan and Hasanagic (2018) and Tura et al. (2019) developed a multi-perspective CE framework including drivers, barriers and practices using systematic literature review approach and case study method respectively, but they did not perform systematic prioritization or analyze interrelationships among the identified factors. Mangla et al. (2018) identified and analyzed barriers to circular supply chain in the Indian automotive industry. However, the Indian context is least acknowledged for $\mathrm{CE}$ implementation with non-existent policy support/direction and very few industries seeking for true circularity at a micro level (Shenoy, 2016). The context of this research, the Chinese food sector, is distinctively different from these few studies in terms of the involved country and industry. China has a history of promoting green and sustainable supply chain practices for over two decades with the later inclusion of CE as part of national development policy since 2008 (Geng et al., 2012, Su et al., 2013). Moreover, for CE implementation different industries may need different supply chain actors to collaborate along with a diverse range of techniques in waste management and resource recovery procedures. Therefore, identification of industry-specific barriers and their interrelationships is necessary for overcoming the implementation challenges.

Globally, food supply chains are responsible for a large amount of solid waste (Hoornweg et al., 2013), greenhouse gas (GHG) emissions (Brundtland, 1987, Genovese et al., 2017), soil degradation, and water and energy consumption (Morone et al., 2019). Global food loss and waste generate around $8 \%$ of total anthropogenic GHG emissions, almost equivalent $(87 \%)$ to global road transport emissions, and ranks as the third top emitter after China and USA (FAO, 
2015). However, research concerning food supply chains' sustainability practices has been scarce. Specifically, the conceptualization of circular food supply chains, i.e., food supply chains that integrate CE philosophy, is missing in the extant literature. It is also unclear what organizational theories can be applied to studying relevant barriers. Therefore, this paper aims to narrow the research gap by achieving the following objectives:

(1) To illustrate the concept of circular food supply chain

(2) To develop a theoretical framework grounded in multiple organizational theories for identifying barriers to integrating $\mathrm{CE}$ into food SCM

(3) To systematically analyze the causal-effect relationships among the barriers in order to find the key barriers in China

This research makes several original contributions. Firstly, it contributes to the literature by advancing the theoretical understanding of circular supply chain - a new sustainability frontier when compared to traditional supply chain sustainability paradigms. Secondly, the research develops a theoretical framework drawing on multiple organizational theories to identify barriers to integrating CE in SCM. Thirdly, to the best of our knowledge, this is the very first research attempt to systematically investigate and prioritize barriers in the Chinese food supply chains context. A Fuzzy Decision-Making Trial and Evaluation Laboratory (DEMATEL) method - a widely recognized scientific prioritization technique for barrier studies (Kaur et al., 2017, Zhu et al., 2014, Venkatesh et al., 2017), is used for analysing the causal-effect relationships among the barriers. Fourthly, this research provides a multi-stakeholder analysis of barriers to circular food supply chains, going beyond the dominant focal firm viewpoint to a dyadic supply chain perspective including downstream supply chain members such as retailers and customers which are least focused (Stone and Rahimifard, 2018, Petljak et al., 2018, Touboulic et al., 2018). Finally, this study offers practical insights into overcoming 
barriers to circular food supply chains in China and other contexts (country and industry) which face similar challenges. It also sheds light on which organizational theories are most suitable for guiding similar studies.

The remainder of the paper is organized as follows. Section 2 reviews the relevant literature. Section 3 conceptualizes circular food supply chain, presents the theoretical framework and identifies barriers. Section 4 explains the fuzzy DEMATEL method and the data collection process. Section 5 presents the results, analysis, and findings. Section 6 discusses research implications, insights and future research directions. Section 7 concludes the research.

\section{Literature Review}

\subsection{CE in China}

Chinese interest in CE was inspired by the recycling laws enacted in Germany and Japan in the late 1990s. In 2004, the Chinese National Development and Reform Commission (NDRC) was assigned the responsibility of promoting CE throughout the country. Soon after, China's 11th five-year plan (2006-2010) devoted a whole chapter on CE, focusing on resource recovery and recycling. In 2007, the NDRC released the first-ever national CE indicators ${ }^{1}$ (Geng et al., 2012). In 2008, the National People's Congress passed the "Circular Economy Promotion Law of the People's Republic of China," making China the first country in the world to legislate CE as part of its national sustainable development policy (Geng et al., 2012, Su et al., 2013).

$\mathrm{CE}$ has been implemented in China at three levels: macro (cities, provinces, and regions), meso (eco-industrial parks), and micro (company or consumer level) (Zhijun and Nailing, 2007,

\footnotetext{
${ }^{1}$ The CE indicators were later updated in 2017. NRDC (National Development and Reform Commission), 2017, "Notice of the Evaluation Index System for the Development of Circular Economy" [Online], Available: http://www.ndrc.gov.cn/zcfb/zcfbtz/201701/t20170112_834922.html [Accessed 16 July 2018. (In Chinese)].]
} 
Ghisellini et al., 2016). Implementation at the macro level involves integration and redesign of the industrial system, infrastructure, cultural framework, and social system, along with support for CE initiatives at city, provincial, and regional levels (Zhijun and Nailing, 2007, Ness, 2008, Ghisellini et al., 2016). For example, macro-level eco-city pilot projects have been implemented in Beijing, Shanghai, Tianjin, and Dalian, aiming to achieve CE goals in relation to resource efficiency, waste prevention, and emissions reduction (Su et al., 2013, Geng et al., 2009).

The meso-level implementation is the development of EIPs, industrial symbiosis districts, and networks (Su et al., 2013, Yuan et al., 2006). In EIPs, industries engage in what is called industrial symbiosis: a complex interaction of resource exchange (material, water, energy, and by-products) and cooperation for waste and pollution reduction to help achieve sustainable development goals (Yu et al., 2015, Ghisellini et al., 2016). The EIP concept was first introduced in China in the late 1990s (Fang et al., 2007). Since then, China under its National Demonstration Eco-industrial Parks (NDEIPs) program and National Pilot Circular Economy Zones (NPCEZs) has developed the world's largest national EIP network consisting of 85 nationally-approved EIPs (as of May 2014), with an additional 26 planned for future construction (Zeng et al., 2017).

The micro-level implementation entails firms incorporating circularity into their production systems and cooperating with supply chain partners to move materials in a circular pattern throughout the supply chains (Winkler, 2011). At this level, eco-design and cleaner production are considered as preparatory CE practices (Ghisellini et al., 2016). Being the most-adopted CE practice globally, cleaner production has been promoted in China under the "Cleaner Production Promotion Law" since 2002 (Su et al., 2013). 
Despite all the developments and efforts, China's progress towards CE has been modest (Mathews and Tan, 2016). The knowledge of CE best practices is still inadequate. There are challenging barriers to making the economy circular (Geng et al., 2009).

\subsection{Supply chain sustainability and circular supply chain}

There has been a great enthusiasm and a growing interest in SCM for CE (Ying and Li-jun, 2012, Aminoff and Kettunen, 2016, Liu et al., 2018, Govindan and Hasanagic, 2018, Bressanelli et al., 2018, Batista et al., 2018b, De Angelis et al., 2018, Batista et al., 2018a, Kazancoglu et al., 2018). For example, as the global e-waste volume increases with economic growth, Awasthi et al. (2018) called for a CE approach to consider e-waste as an opportunity for recycling or recovery of valuable metals. In the SCM literature on sustainability, a number of concepts, such as sustainable supply chains, green supply chains, environmental supply chains, and closed-loop supply chains, have been introduced and sometimes being used interchangeably (Gurtu et al., 2015) to express the integration of sustainability concepts in SCM (Ahi and Searcy, 2015). Green, environmental and sustainable SCM practices have been largely focused on environmental/ecological impacts, corporate governance, and social issues respectively (Batista et al., 2018a). Similarly, closed-loop supply chains consider simultaneous forward and reverse supply chain operations (Govindan and Soleimani, 2017). Table 1 present some of the most cited definitions of supply chain sustainability terms in the extant literature. 
Table 1: Definitions of supply chain sustainability terms

\begin{tabular}{|c|c|c|}
\hline $\begin{array}{c}\text { Supply chain } \\
\text { sustainability terms }\end{array}$ & Authors & Definition \\
\hline Sustainable SCM & $\begin{array}{l}\text { Seuring and Müller } \\
\qquad(2008)\end{array}$ & $\begin{array}{l}\text { "The management of material, information and capital flows as well as } \\
\text { cooperation among companies along the supply chain while taking goals from } \\
\text { all three dimensions of sustainable development, i.e., economic, environmental } \\
\text { and social, into account which are derived from customer and stakeholder } \\
\text { requirements". }\end{array}$ \\
\hline Green SCM & Srivastava (2007) & $\begin{array}{l}\text { "Integrating environmental thinking into supply-chain management, including } \\
\text { product design, material sourcing and selection, manufacturing processes, } \\
\text { delivery of the final product to the consumers as well as end-of-life } \\
\text { management of the product after its useful life". }\end{array}$ \\
\hline Environmental SCM & $\begin{array}{l}\text { Zsidisin and Siferd } \\
\qquad(2001)\end{array}$ & $\begin{array}{l}\text { "The set of supply chain management policies held, actions taken, and } \\
\text { relationships formed in response to concerns related to natural environment } \\
\text { with regards to the design, acquisition, production, distribution, use, reuse, and } \\
\text { disposal of the firm's goods and services". }\end{array}$ \\
\hline $\begin{array}{c}\text { Closed Loop Supply } \\
\text { chains }\end{array}$ & $\begin{array}{c}\text { Guide and Van } \\
\text { Wassenhove (2006) }\end{array}$ & $\begin{array}{l}\text { "Design, control, and operation of a system to maximize value creation over } \\
\text { the entire life cycle of a product with the dynamic recovery of value from } \\
\text { different types and volumes of returns over time". }\end{array}$ \\
\hline
\end{tabular}

From Table 1, it is evident that these traditional supply chain sustainability terms represent different degrees of sustainable thinking in supply chains. However, none of them have integrated the circular thinking (i.e. the essence of the CE philosophy) into SCM (Masi et al., 2017, Malviya and Ravi, 2015, Liu et al., 2018, Mishra et al., 2018, Larsen et al., 2018, Kazancoglu et al., 2018, Bernon et al., 2018, Lapko et al., 2018). CE significantly enhances supply chain sustainability narrative by integrating a restorative and regenerative design thinking (Batista et al., 2018a). Another important aspect differentiating CE from existing sustainability thinking is its "zero-waste" vision (Veleva et al., 2017). Circular supply chains consider waste as a resource; hence it is designed to regenerate natural capital to the biosphere so that biological materials can be utilized again and again indefinitely via subsequent ecological cycles of plants and animals. 


\subsection{Food supply chain sustainability in China and CE related barrier studies}

As mentioned earlier, the Food and Agriculture Organization (FAO) of the United Nations estimates that about one-third of edible food (approximately 1.3 billion tons) is lost or wasted throughout global food supply chains (i.e., from initial agricultural production to final household consumption) (FAO (Food and Agricultural Organisation), 2011). Moreover, the sustainability of food supply chains is threatened by other issues including growing population, increasing demand for food, inefficiencies in resource use and food distribution, and severe environmental impacts. Integrating $\mathrm{CE}$ into food $\mathrm{SCM}$ is a potentially viable solution to resolve waste management challenges in the Chinese food supply chains (Jurgilevich et al., 2016). At present, there is a high percentage of food remnants in municipal solid waste in China due to the lack of source separation, resulting in incineration difficulties for waste-to-energy production (Tai et al., 2011). Although food supply chains are an essential part of a CE implementation driven by the Chinese government (Mylan et al., 2016), yet research in this domain has been scarce. The extant literature offers little understanding of the barriers to circular food supply chains in China.

Some relevant studies have broadly discussed barriers to implementing CE in China at a macro level. Table 2 summarizes the contexts and scopes of these studies, along with a few available barrier studies in different countries. Apparently, they do not cover specific barriers to circular food supply chains in China. 
Table 2: Previous studies on barriers to CE implementation

\begin{tabular}{|c|c|c|c|}
\hline Authors & Research Context & Scope & Methodology \\
\hline $\begin{array}{c}\text { Geng and } \\
\text { Doberstein (2008) }\end{array}$ & $\begin{array}{l}\text { China; Industry not } \\
\text { specified }\end{array}$ & $\begin{array}{l}\text { CE at a macro } \\
\text { level }\end{array}$ & Review paper \\
\hline Shi et al. (2008) & $\begin{array}{c}\text { China; Industry not } \\
\text { specified (SME's sector) }\end{array}$ & $\begin{array}{c}\text { Cleaner } \\
\text { production } \\
\text { at a micro level } \\
\end{array}$ & $\begin{array}{c}\text { Analytic hierarchy } \\
\text { process } \\
(\mathrm{AHP}) \\
\end{array}$ \\
\hline Geng et al. (2009) & $\begin{array}{c}\text { China; Industry not } \\
\text { specified }\end{array}$ & $\begin{array}{c}\text { CE at a macro } \\
\text { level }\end{array}$ & $\begin{array}{l}\text { Review paper } \\
\text { (country report) }\end{array}$ \\
\hline Geng et al. (2010) & $\begin{array}{c}\text { China; Industry not } \\
\text { specified }\end{array}$ & $\begin{array}{c}\text { CE at a macro } \\
\text { level }\end{array}$ & Case study \\
\hline Su et al. (2013) & $\begin{array}{l}\text { China; Industry not } \\
\text { specified }\end{array}$ & $\begin{array}{c}\text { CE at a macro } \\
\text { level }\end{array}$ & Review paper \\
\hline $\begin{array}{c}\text { Govindan and } \\
\text { Hasanagic (2018) }\end{array}$ & $\begin{array}{l}\text { Research context not } \\
\text { specified }\end{array}$ & $\begin{array}{l}\text { CE at macro, } \\
\text { meso and micro } \\
\text { levels. }\end{array}$ & Review paper \\
\hline $\begin{array}{l}\text { Mangla et al. } \\
\quad(2018)\end{array}$ & $\begin{array}{l}\text { India; Automotive } \\
\text { Industry }\end{array}$ & $\begin{array}{l}\text { CE at meso and } \\
\text { micro levels. }\end{array}$ & $\begin{array}{l}\text { Interpretive Structural } \\
\text { Modelling (ISM) }\end{array}$ \\
\hline Tura et al. (2019) & $\begin{array}{l}\text { Finland; Multiple } \\
\text { Industries }\end{array}$ & $\begin{array}{c}\text { CE at macro, } \\
\text { meso and micro } \\
\text { levels. }\end{array}$ & Case study \\
\hline
\end{tabular}

Summarizing the literature review, the concept of circular supply chain represents a new frontier in supply chain sustainability thinking. Its zero-waste vision is far more sustainable than those of traditional supply chain sustainability concepts. Furthermore, circular supply chain's zero-waste vision is not only inspirational but also achievable by regenerative and restorative design of products and their supply chain processes. China has legislated CE as part of its national development strategy; however, barriers persist in its transition to making the economy circular. Food industry is of strategic importance to the world, but little research has investigated barriers to circular food supply chains. This research narrows an important literature gap by studying the barriers to circular food supply chains in China and by systematically prioritizing the causal-effect relationships among the barriers. 


\section{Circular food supply chains and their barriers in China}

\subsection{Conceptualizing circular food supply chain}

Figure 1 illustrates the concept of circular food supply chain. Unlike a liner food supply chain sending waste to landfill at multiple supply chain stages, a circular food supply chain has a zero-waste vision. It requires a complete rethinking by integrating circularity in the design of food products, their packaging and supply chain processes. On one hand, waste generation should be designed out of the supply chain system, or at least be minimized at all supply chain stages. On the other hand, a collection system must be in place for unavoidable wastes generated along various supply chain stages including agricultural production, postharvest handling and storage, processing, distribution, and consumption (Liu, 2014) for resource recovery purposes. CE mimics the natural ecosystem by transforming the so-called waste into valuable feedstock through its regenerative cycle and thereby allows the transition to circular supply chains (EMF, 2012, Morone et al., 2019).

There are success stories of circular food supply chains which enable value creation networks of facilities for cascading value from organic by-products (Borrello et al., 2016). For example, Enterra Feed Corporation (Canada) uses a black soldier fly (Hermetia illucens) to naturally bioconvert unsold food collected from local grocers and food processors into feedstock and fertilizer (Vickerson, 2016). Other applications include bio-refineries where, agri-food residues are transformed into proteins, sugars, plastics, medicines, and fuel using enzymes and bacteria (Mirabella et al., 2014). Despite a promising future and a growing interest in circular food supply chains, such applications are still very rare. There are challenging barriers impeding the development and implementation of circular food supply chains. 


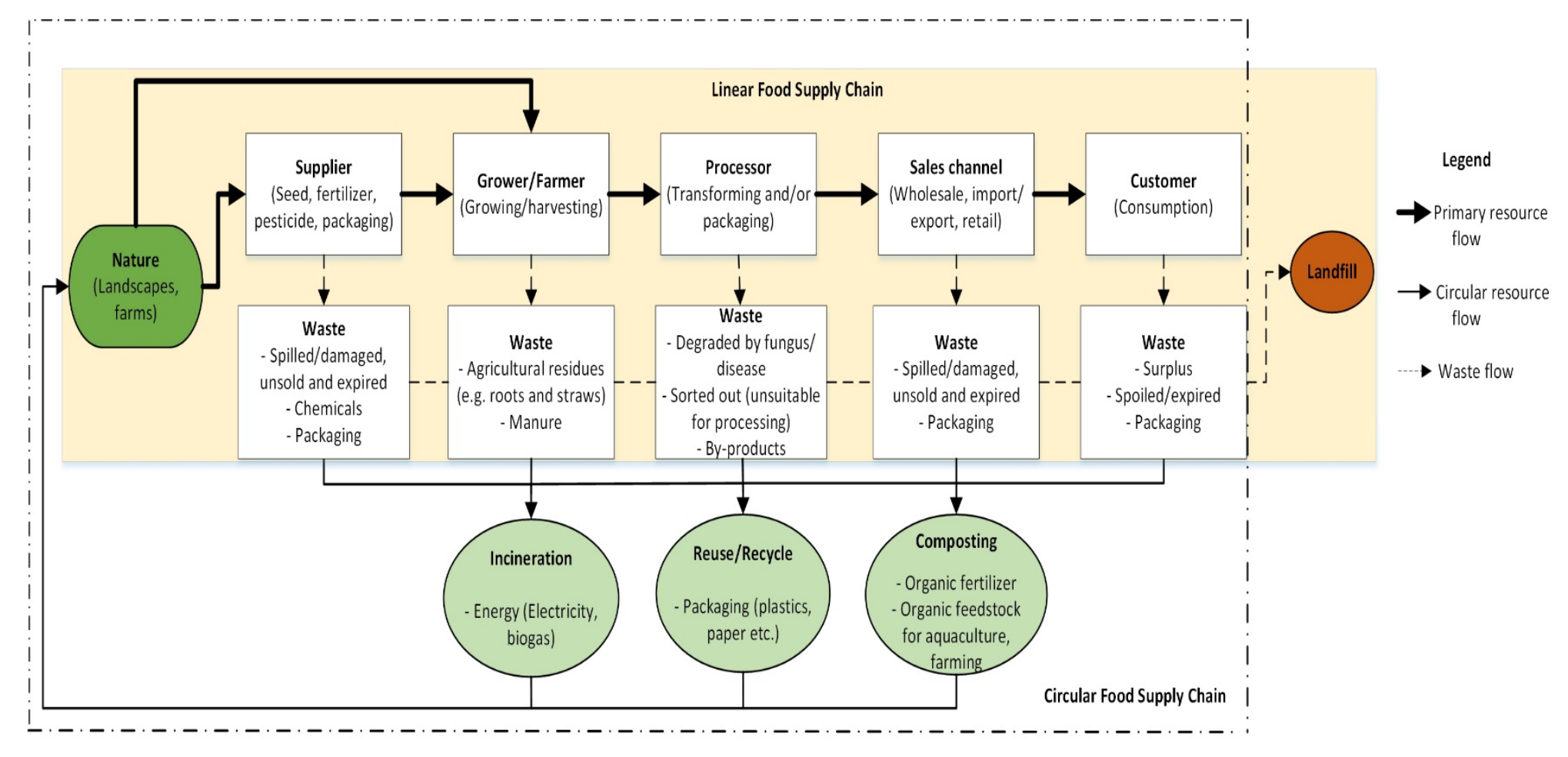

Figure 1: Circular Food Supply Chain

\subsection{Theoretical Framework for Identifying Barriers in China}

This research develops a theoretical framework for identifying barriers to integrating CE in SCM. Following Carter and Dale's (2008) example, the framework is grounded in several of the most well-recognized organizational theories. The conceptualization of the framework was an iterative process involving a concentrated review of the literature, synthesis, and refinement. Overall, we followed a two-stage process for framework development. In the first stage, an initial list of barriers was prepared through extensive literature review. A series of discussions on the initial list of barriers were held with two academicians specialized in supply chain sustainability and CE, and three government officials representing regional 'Development and Reform Commission' in China. As a result, the most relevant barriers were shortlisted, categorized and described in light of the organizational theories. In the second stage, three rounds of focus group meetings were organized with over 30 participants managing food supply chains. Overall, their inputs helped to refine the list of barriers and ensure validity in the wider economic, social and political context in China (Yin, 2013). 
The resource-based view (RBV) of the firm explains how firms achieve sustained abovenormal returns and competitive advantages by drawing on distinctive resources and capabilities (Barney, 1991, Rugman and Verbeke, 2002). The RBV defines resources as "all assets, capabilities, organizational processes, firm attributes, information, knowledge, etc. controlled by a firm that enable the firm to conceive of and implement strategies that improve its efficiency and effectiveness" (Barney, 1991, p. 101). These resources can include human, information technology, capital, equipment and knowledge resources (Sarkis et al., 2010). The adoption of environmentally-friendly practices depends on the interplay of organizational culture and managerial process involving various human resource factors as identified by Daily and Huang (2001). In this regard, the dynamic capabilities theory, rooted in the RBV (Rugman and Verbeke, 2002, Barney, 1991), offers a precise theoretical lens through which to understand this phenomenon. The term dynamic capabilities refer to a firm's ability to maintain a fit with its changing business environment (Teece et al., 1997). The dynamic fit is achieved by appropriately developing management capabilities, new resource configurations and organizational thoughts (Rauer and Kaufmann, 2015, Eisenhardt and Martin, 2000, Lawson and Samson, 2001).

From the dynamic capabilities and RBV perspectives, an organization's inability to acquire strategic resources and develop capabilities to innovate sustainability practices could be a barrier to integrating CE in SCM. Implementing CE can be costly and requires upfront investment (Geng et al., 2009). Therefore, lack of financial resources has always been a major hurdle in CE implementation, particularly for small and medium-sized enterprises (SMEs) (Shi et al., 2008, Walker et al., 2008). Moreover, integrating the restorative and regenerative philosophies of $\mathrm{CE}$ in the existing food supply chain systems means facing technical and technological challenges. Limited technical expertise (Shi et al., 2008) and lack of information on CE-compatible technologies (Geng and Doberstein, 2008) and on industry best 
practices/performance indicators impede the integration of CE in SCM. Furthermore, lack of management commitment and inadequate capacity, resistance to change (Shi et al., 2008), and inconducive organizational culture all limit organizational vision and managerial approach, in turn, limiting the development of dynamic capabilities to adopt and implement CE. Therefore, drawing on theoretical arguments in $\mathrm{RBV}$, we put forward the following three barriers:

\section{B1: Lack of financial resources}

B2: Limited expertise, technology, and information

B3: Organizational culture and management

Contingency theory describes a firm's performance as an outcome of "fit or match" between its structure and processes on one hand and environmental conditions on the other (Lawrence and Lorsch, 1967, Miller, 1987). According to contingency theory, firms often shape their business environment by formulating appropriate strategies to deal with uncertainty (Thompson, 1967). CE implementation, then, is contingent on the environmental and economic benefits associated with it (Geng et al., 2009). Therefore, barriers exist when the management is uncertain about the benefits, and especially when the current processes and technologies are still profitable (Shi et al., 2008). In addition, the implications of high cost (Giunipero et al., 2012) and lack of economies of scale with CE serve as barriers to integrating CE in SCM. Therefore, we put forward the following two barriers:

B4: Uncertainty about benefits

B5: Lack of economies of scale

Institutional theory (DiMaggio and Powell, 1983) explains how organizations respond to institutional pressures; seek to adopt or legitimize themselves in the sight of stakeholders; and adopt homogeneous, institutionalized structures and practices (North, 1990, Jennings and Zandbergen, 1995). There are three types of institutional pressure - coercive, mimetic, and 
normative isomorphism. Coercive isomorphism exists where powerful stakeholders such as government agencies and regulatory bodies impose certain rules and regulations. Mimetic isomorphism is when organizations imitate competitors' path to success. Normative isomorphism is related to external stakeholders such as customers, non-government organizations, pressures groups, and media organizations that demand what constitutes appropriate and legitimate behavior. Institutional theory shares some common understandings with stakeholder theory (Donaldson and Preston, 1995, Freeman, 2010). The latter suggests that companies produce externalities that affect many stakeholders (both internal and external to the firm), and that the subsequent pressure from those stakeholders results in significant motivation for organizations to adopt proactive environmental strategies (Buysse and Verbeke, 2003).

Ample research has provided evidence that institutional and stakeholder pressures have driven the adoption of environmentally friendly practices (Sarkis et al., 2010, Zhu and Sarkis, 2007, Zhu et al., 2013, Hsu et al., 2013). Conversely, the lack of pressure or inappropriate pressure mechanisms can be barriers (Walker et al., 2008). For example, Geng and Doberstein (2008) believe that China's legal system does not provide a unified platform to promote innovations like $\mathrm{CE}$ due to its fragmented policies. Other studies have also mentioned weak environmental regulations and enforcement as barriers to environmentally friendly practices (Geng et al., 2010, Walker et al., 2008). Geng et al. (2010) further argue that the Chinese political system does not provide a formal institutional channel through which the general public can influence environmental policies. Thus, low public awareness of and participation in CE activities has been a barrier to promoting CE (Geng et al., 2009). Therefore, we consider the following two barriers to integrating $\mathrm{CE}$ in SCM. 
B6: Weak environmental regulations and enforcement

B7: Lack of market preference/pressure

Furthermore, integrating CE in SCM requires supply chain actors to collaborate and support each other. In this regard, we borrow insights from the resource dependence theory (Pfeffer and Pfeffer, 1981, Pfeffer, 1972). This theory proposes that organizations are interdependent (Finkelstein, 1997). Hence, barriers could arise when an organization's supply chain actors are not willing to collaborate and support the implementation of CE. Therefore, we consider the following barrier.

B8: Lack of collaboration/support from supply chain actors

Figure 2 presents the theoretical framework of identified barriers which hinder the integration of CE in SCM. Table 3 provides a complete description of the identified barriers.

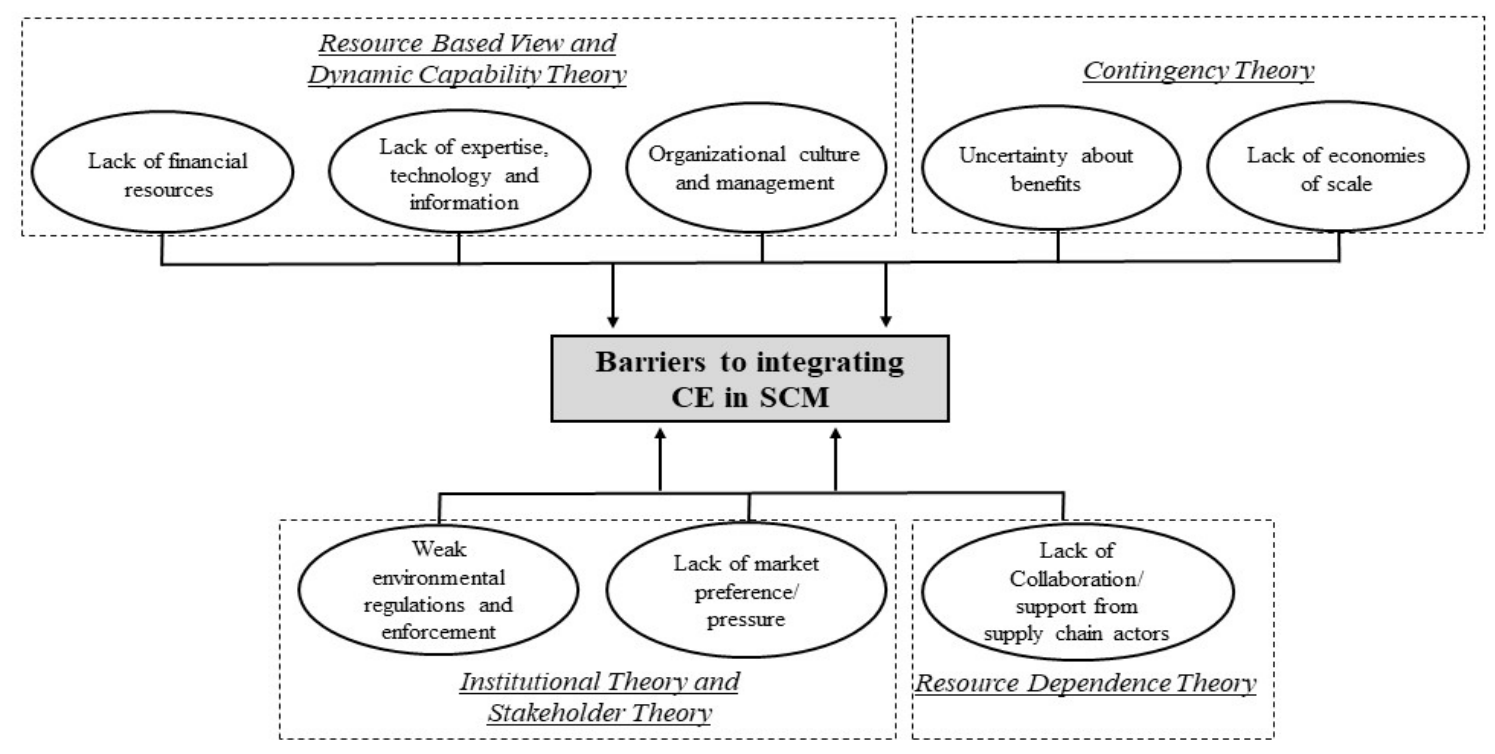

Figure 2: A theoretical framework for identifying barriers to integrating CE in SCM 
Table 3: Description of barriers

\begin{tabular}{|c|c|}
\hline Barriers & Description \\
\hline B1: Lack of financial resources & Lack of financial resources available to implement CE \\
\hline $\begin{array}{l}\text { B2: Limited expertise, technology, and } \\
\text { information }\end{array}$ & $\begin{array}{l}\text { Lack of design, process, and supply chain expertise, } \\
\text { technology, and/or technical support } \\
\text { Lack of information about the available technologies and best } \\
\text { practices }\end{array}$ \\
\hline B3: Organizational culture and management & $\begin{array}{l}\text { Organizational culture hinders the adoption of } \mathrm{CE} \\
\text { Lack of management commitment, and inadequate } \\
\text { management capacity } \\
\text { Resistance to change }\end{array}$ \\
\hline B4: Uncertainty about benefits & $\begin{array}{l}\text { Uncertainty about the potential environmental and economic } \\
\text { benefits of CE including subsidies/tax benefits } \\
\text { Implementing CE practices requires replacement of current } \\
\text { technologies that are still profitable }\end{array}$ \\
\hline B5: Lack of economies of scale & $\begin{array}{l}\text { Lack of economies of scale in implementing CE } \\
\text { High cost of implementing CE and the possible adverse effect } \\
\text { on scale economy }\end{array}$ \\
\hline $\begin{array}{l}\text { B6: Weak environmental regulations and } \\
\text { enforcement }\end{array}$ & $\begin{array}{l}\text { Weak environmental regulations and enforcement to support } \\
\text { CE implementation }\end{array}$ \\
\hline B7: Lack of market preference/pressure & $\begin{array}{l}\text { Lack of market preference and pressure from both customers } \\
\text { and consumers }\end{array}$ \\
\hline $\begin{array}{l}\text { B8: Lack of collaboration/support from supply } \\
\text { chain actors }\end{array}$ & $\begin{array}{l}\text { Supply chain actors are reluctant to collaborate/support CE } \\
\text { initiatives }\end{array}$ \\
\hline
\end{tabular}

\section{Methodology}

\subsection{Questionnaire development and data collection}

A questionnaire was designed, in English, to facilitate the data collection for DEMATEL analysis, capturing the views of evaluators, based on our theoretical framework presented above. The questionnaire provided an explanation of the study objectives and description of each barrier to guide the evaluators. It was then translated into the Chinese language. Two researchers proficient in both English and Chinese checked it to ensure an accurate translation. Two rounds of pilot tests were conducted with three evaluators to get feedback about the design of the questionnaire. Based on their feedback, two rounds of revisions were made to ensure content validity by eliminating ambiguity and possible confusion. 
The finalized questionnaire was randomly distributed to 300 potential evaluators by email or post to be anonymously completed by senior executives/managers/supply chain heads and business owners. A convenience sampling method was adopted to seek responses from customers. The distribution and collection of the questionnaire were supported by three branches of a regional government in northern China, namely, Development and Reform Commission, the Bureau of Commerce, and Food Safety Committee. Senior officials from these government departments were also requested to participate as evaluators considering their active involvement in CE implementation being an external supply chain stakeholder. Efforts were made to involve evaluators who represent farmers/farming cooperatives. However, after analysing the first six responses from farmers/farming cooperatives, the researchers were concerned about data quality and decided to exclude them from the research scope to ensure the validity and reliability of the whole data set. The data quality issue associated with farmers/farming cooperatives is complex. The researchers suspected a diverse range of potential causes including the complexity of the CE concept which was difficult for many farmers to fully comprehend, the respondents' limited knowledge on supply chain dynamics beyond the farm gate, and their lack of incentives to participate in the research.

The final evaluators involved in this research are categorized into four groups: food processors (food processing/manufacturing companies), sales and distribution channels (supermarkets, import/export businesses, e-retailers, and wholesalers), customers (buyers/consumers of the final product) and government officials (external supply chain stakeholder). A total of 112 questionnaires were returned, among which 105 complete responses were considered valid for the DEMATEL analysis. Table 4 shows the classification of these 105 evaluators. More details about the evaluators are given in Appendix A. 
Table 4: Classification of evaluators

\begin{tabular}{|c|c|c|c|}
\hline Group & Evaluator type & Frequency & Percentage \\
\hline Food processor & Food processors/manufacturers & 32 & $30.5 \%$ \\
\hline Sales \& distribution channel & $\left.\begin{array}{l}\text { Supermarket (13) } \\
\text { Import/Export (9) } \\
\text { E-Retailer (6) } \\
\text { Wholesaler (3) }\end{array}\right]$ & 31 & $29.5 \%$ \\
\hline Customer & Buyers/consumers & 35 & $33.3 \%$ \\
\hline Government & Government officials & 7 & $6.7 \%$ \\
\hline Total number of evaluators & & 105 & $100 \%$ \\
\hline
\end{tabular}

\subsection{Barrier study techniques}

To uncover the complicated interdependencies among barriers, it is necessary to employ a scientific prioritization tool. In the extant literature, a number of sophisticated techniques are available to perform such analysis including Interpretive Structural Modelling (ISM), Analytic Hierarchy Process (AHP), Analytic Network Process (ANP), Structural Equation modelling (SEM) etc. However, in recent years, the DEMATEL technique has become increasingly popular (Venkatesh et al., 2017). It is centred on graph theory and analyses the complex causal relationships through quantitative methods (via matrices and diagrams) (Shao et al., 2016, Fu et al., 2012). Table 5 provides a comparison of DEMATEL with the above-mentioned research methods.

Table 5: A comparison of DEMATEL with ISM/AHP/ANP/SEM

\begin{tabular}{|c|c|c|c|c|}
\hline DEMATEL & ISM & AHP & ANP & SEM \\
\hline $\begin{array}{l}\text { DEMATEL helps } \\
\text { to uncovers the } \\
\text { causal interactions } \\
\text { among the variables } \\
\text { based on their } \\
\text { cause and effect } \\
\text { groups }\end{array}$ & $\begin{array}{l}\text { ISM uncovers the } \\
\text { contextual } \\
\text { interactions among } \\
\text { variables based on } \\
\text { their driving } \\
\text { potential and } \\
\text { dependencies }\end{array}$ & $\begin{array}{l}\text { AHP does not } \\
\text { provide any } \\
\text { interdependencies } \\
\text { between and among } \\
\text { the variables, rather } \\
\text { used to draw the } \\
\text { hierarchical } \\
\text { structure of the } \\
\text { variables }\end{array}$ & $\begin{array}{l}\text { ANP can provide } \\
\text { interdependencies } \\
\text { between and among } \\
\text { the variables; this } \\
\text { method is less } \\
\text { accepted due to its } \\
\text { complexity }\end{array}$ & $\begin{array}{l}\text { SEM is an 'a priori' } \\
\text { method, mainly } \\
\text { used for theoretical } \\
\text { development. SEM } \\
\text { requires a } \\
\text { large sample size }\end{array}$ \\
\hline
\end{tabular}

Source: Adopted from Mangla et al. (2018) 
Both DEMATEL and ISM can analyze the interrelationship among factors (Baykasoğlu and Gölcük, 2015). However, according to Kumar and Dixit (2018), ISM is a macro-oriented approach used to breakdown complex systems into sub-systems. Whereas, DEMATEL is a relatively micro-oriented approach that helps to determine the intensity of relationships (both direct and indirect) among the variables as well as to visualize causal relationships through impact-relations map (Kumar and Dixit, 2018). Thus, DEMATEL was found to be more suitable than ISM for this study.

ANP is an extension to the AHP method (Saaty, 2013). The main benefits of ANP over AHP are its ability to make more accurate predictions and priority calculations in case of networks with dependent criteria. However, ANP does not provide interrelationships among variables and that is where DEMATEL is considered more advantageous (Vujanović et al., 2012).

Highlighting the well-established fact that correlation does not establish causality, Guide and Ketokivi (2015) advocated the use of correct methods when making causality claims. Statistical techniques such as regression and SEM analysis do not automatically establish causality. Moreover, these techniques typically require specific parametric assumptions for the data besides requiring a large sample size (Bai and Sarkis, 2013). DEMATEL is more suitable for barrier studies than multivariate regression analysis and SEM as the latter techniques were not designed to fully evaluate the interactions and causal relationships among various factors (Dou et al., 2014, Hu et al., 2011). However, with the DEMATEL technique, causal dimensions of a complex system are converted into a structural model that is easy to understand, further visualizing them into cause and effect groups (Gandhi et al., 2015, Kaur et al., 2017). It is also used to rank the variables and does not require a large amount of data (Bai et al., 2017).

The comparisons presented above explain why DEMATEL is well suited for barrier studies. Some recent DEMATEL based barrier studies in the supply chain sustainability domain include 
low-carbon supply chain cooperation practices (Bai et al., 2017), green SCM practices (Kaur et al., 2017, Gandhi et al., 2015) and renewable energy resources selection (Büyüközkan and Güleryüz, 2016).

\subsection{Fuzzy DEMATEL technique}

This study used a fuzzy DEMATEL approach to overcome the inherent vagueness and bias in human judgments (Govindan et al., 2015b, Govindan et al., 2015a, Wu and Lee, 2007, Tseng et al., 2013). Triangular fuzzy numbers (TFNs) ranging between 0 and 1 were used to denote the linguistic expressions of the evaluators.

As in previous studies (Lin, 2013, Zhu et al., 2014, Venkatesh et al., 2017, Kaur et al., 2017), a six-step DEMATEL process was used to prioritize the barriers and examine their interrelationships.

Step 1: Developing a fuzzy pairwise comparison matrix

In the first step, we defined a fuzzy pairwise comparison scale to develop the initial directrelation matrix. We used the following five-point scale: $0=$ no influence, $1=$ very low influence, $2=$ low influence, $3=$ high influence and $4=$ very high influence. Following the steps of previous studies (Wu, 2012, Venkatesh et al., 2017), the fuzzy linguistic scale values and their corresponding TFNs are shown in table 6.

Table 6: Fuzzy linguistic scale

\begin{tabular}{lll}
\hline Scale values & Linguistic variable & Corresponding TFNs \\
\hline 0 & No Influence (NO) & $0,0,0.25$ \\
1 & Very Low Influence (VL) & $0,0.25,0.5$ \\
2 & Low Influence (L) & $0.25,0.5,0.75$ \\
3 & High Influence $(\mathrm{H})$ & $0.5,0.75,1.0$ \\
4 & Very high Influence $(\mathrm{VH})$ & $0.75,1.0,1.0$ \\
\hline
\end{tabular}


The evaluators completed a pairwise comparison of the barriers using the scale provided in Table 6. Moreover, they ranked the barriers in order of their importance, based on their industry knowledge and experience. Through this approach, we could compare the DEMATEL rankings with the important rankings provided by the evaluators. A sample of pairwise comparison and importance ranking is shown in Appendix B.

Step 2: Obtaining a fuzzy pairwise initial direct-relation matrix (A)

The initial direct-relation matrix was transformed into a crisp matrix by the defuzzification process to obtain initial direct-relation matrix (A). We used a weighted average method to defuzzify the direct-relation matrix, following a previous study by Venkatesh et al. (2017).

Step 3: Developing a normalized direct-relation matrix (D)

The normalized direct-relation matrix (D) was obtained through equations (1) and (2).

$$
\begin{gathered}
m=\min \left[\frac{1}{\max \sum_{\mathrm{j}=1}^{\mathrm{n}}|\mathrm{a} i j|}\right],\left[\frac{1}{\max \sum_{\mathrm{i}=1}^{\mathrm{n}}|a i j|}\right] \\
D=m \times A
\end{gathered}
$$

Step 4: Developing a total relations matrix (T)

The total relation matrix (T) was developed based on Equation (3), where $I$ represents an $n \times$ $n$ identity matrix. The total relation matrices (T) are shown in Appendix C.

$$
T=(I-D)^{-1}
$$

Where $I=$ Identity matrix; $T=$ Total relation matrix, $T=[\mathrm{t} i j] n \times n$

Step 5: Calculating the sum of rows $(R)$ and sum of columns $(C)$

The computation of the sum of rows (R) and sum of columns (C) was performed using equations (4) and (5). 


$$
\begin{aligned}
& R=\left[\sum_{j=1}^{n} \mathrm{t} i j\right] n \times 1 \\
& C=\left[\sum_{j=1}^{n} \mathrm{t} i j\right] 1 \times n
\end{aligned}
$$

\section{Step 6: Drawing a prominence-causal relationship diagram}

The row values $(\mathrm{R})$ represent the overall effects produced by barrier $i$ on barrier $j$. Similarly, the column values (C) represent the overall effects on barrier $i$ from barrier $j$. Moreover, the prominence value $(R+C)$ and net causal-effect value $(R-C)$ were also calculated. A barrier with a high prominence value deserves immediate attention because its total influences are significant, i.e., affecting other barriers while also being affected by other barriers. A barrier with a high net causal-effect value is of fundamental importance as it is a root cause of other barriers (Zhu et al., 2014, Venkatesh et al., 2017).

\section{Results, analysis, and findings}

The overall DEMATEL results (prominence/net cause-effect values and evaluators' importance rankings) are summarized in Table 7. The prominence-causal relationship diagrams were developed for all evaluating groups. These diagrams are mapped in Figure 3. The arrows represent interrelationships between barriers, with a one-way arrow representing a one-way relationship and a two-way arrow, a two-way relationship. We only mapped significant relationships above a threshold value $(\varnothing)$ calculated by adding one standard deviation to the mean of the total relation matrix (T) as a benchmark following $\mathrm{Fu}$ et al. (2012). All the significant relationships (above $\varnothing$ value) are highlighted as bold values in Appendix E. These significant relationships are also plotted in Figure 3. 
Table 7: A summary of evaluators' importance rankings and DEMATEL analysis results

\begin{tabular}{ccccccccccccc}
\hline & \multicolumn{3}{c}{ Food Processors } & \multicolumn{3}{c}{ Sales \& Distribution Channels } & \multicolumn{3}{c}{ Customers } & \multicolumn{3}{c}{ Government Officials } \\
\cline { 2 - 12 } Barriers & R+C & R-C & Ranking* & R+C & R-C & Ranking* & R+C & R-C & Ranking* & R+C & R-C & Ranking* \\
\hline B1 & 13.49 & -0.33 & 1 & 24.51 & 0.66 & 2 & 7.89 & -0.11 & 1 & 14.14 & -0.36 & 1 \\
B2 & 13.73 & -0.62 & 2 & 23.63 & -0.87 & 1 & 7.74 & -0.36 & 3 & 13.09 & -0.40 & 2 \\
B3 & 12.96 & -0.41 & 5 & 25.51 & 0.90 & 3 & 8.10 & -0.03 & 2 & 12.53 & -0.27 & 3 \\
B4 & 12.41 & -0.19 & 6 & 24.15 & -0.14 & 6 & 7.25 & 0.08 & 7 & 12.67 & -0.99 & 6 \\
B5 & 12.19 & 0.74 & 3 & 23.46 & 0.68 & 7 & 6.60 & 1.54 & 4 & 11.55 & 2.25 & 8 \\
B6 & 11.66 & 0.21 & 7 & 24.73 & 0.34 & 5 & 7.35 & 0.85 & 5 & 10.33 & 1.49 & 5 \\
B7 & 12.00 & 0.92 & 8 & 25.04 & -1.34 & 8 & 8.26 & -1.18 & 8 & 13.42 & -1.11 & 6 \\
B8 & 14.47 & -0.32 & 4 & 25.73 & -0.25 & 4 & 8.41 & -0.79 & 6 & 14.09 & -0.61 & 3 \\
\hline
\end{tabular}

*Evaluator group's importance rankings

Table 7 and Figure 3 show some disparities in the results on key barriers across the four evaluating groups. This seems logical given the difference in their roles in food supply chains. As shown in Figure 3(a), food processors consider lack of market preference/pressure (B7), lack of economies of scale (B5) and weak environmental regulations and enforcement (B6) as the most significant cause barriers. Sales and distribution channels (see Figure 3(b)) categorize uncertainty about benefits (B4), weak environmental regulations and enforcement (B6), lack of financial resources (B1) and lack of market preference/pressure (B7) as the most significant cause barriers. Results in Figure 3(c) show that customers identify weak environmental regulations and enforcement (B6), lack of market preference/pressure (B7) and organizational culture and management (B3) as significant cause barriers. The government officials group as an external stakeholder identified weak environmental regulations and enforcement (B6) and lack of market preference/pressure (B7) as significant cause barriers (Figure 3(d)). 


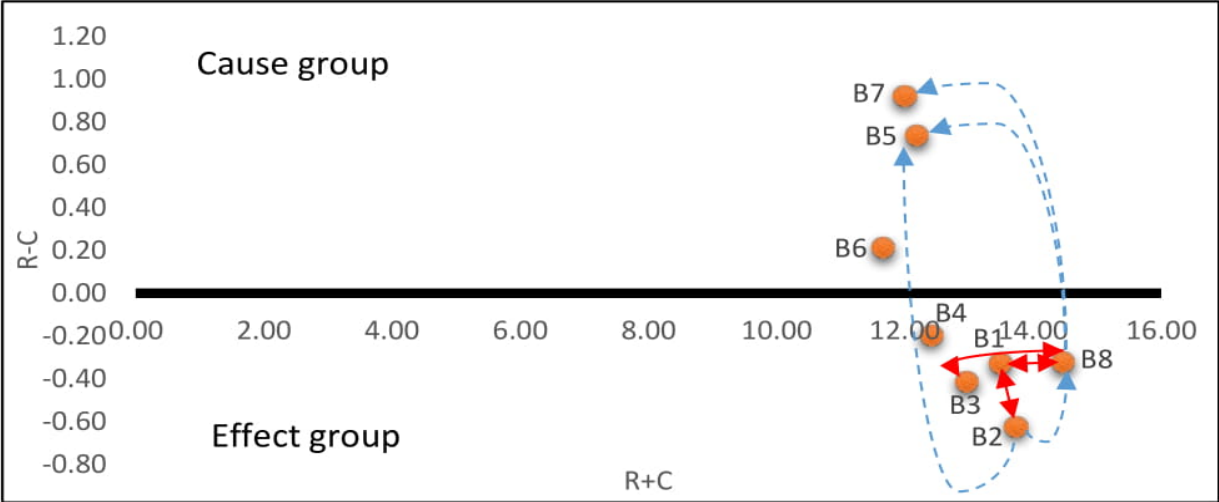

Significant relationships: B1-B8, B2-B1, B2-B5, B2-B8, B3-B8, B8-B5, B8-B7

$$
\text { a) Food processors }
$$

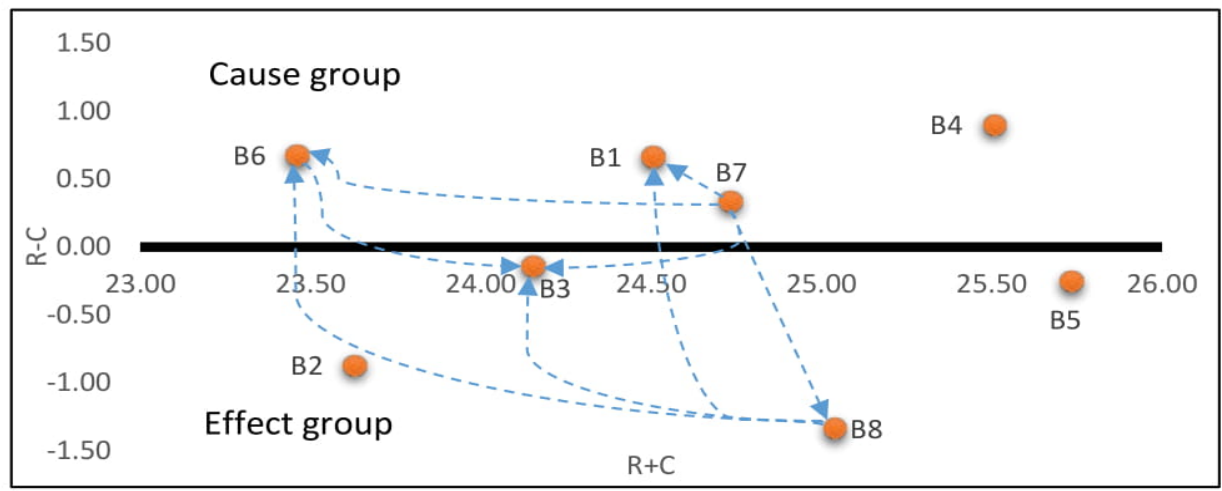

Significant relationships: B6-B3, B7-B1, B7-B3, B7-B6, B7-B8, B8-B1, B8-B3, B8-B6

b) Sales \& distribution channels

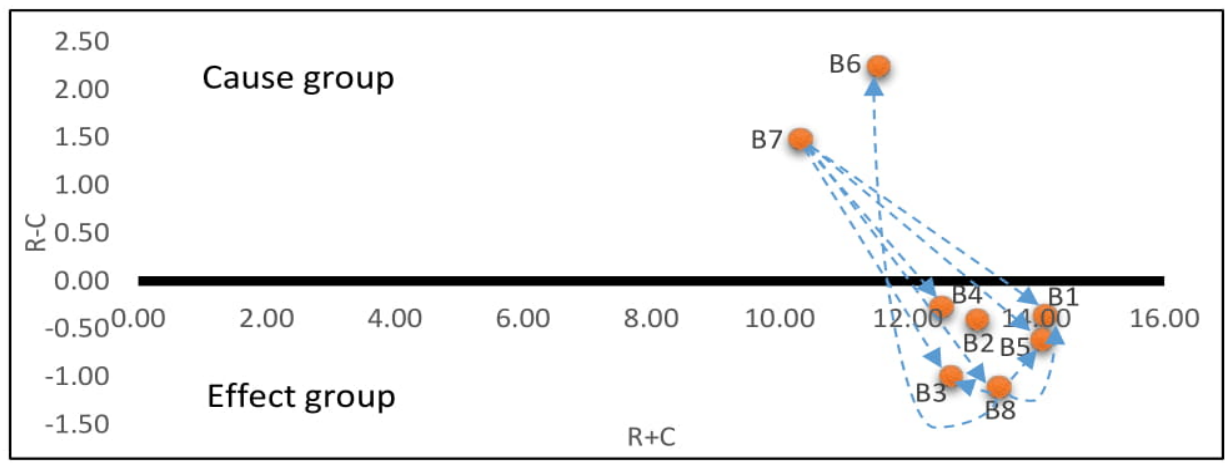

Significant relationships: B7-B1, B7-B3, B7-B4, B7-B5, B7-B6, B7-B8, B8-B1, B8-B3, B8-B5, B8-B6

c) Customers

\section{Barrier definition:}

B1: Lack of financial resources

B2: Limited expertise, technology, and information

B3: Organizational culture and management

B4: Uncertainty about benefits

B5: Lack of economies of scale

B6: Weak environmental regulations and enforcement

B7: Lack of market preference/pressure

B8: Lack of collaboration/ support from supply chain actors

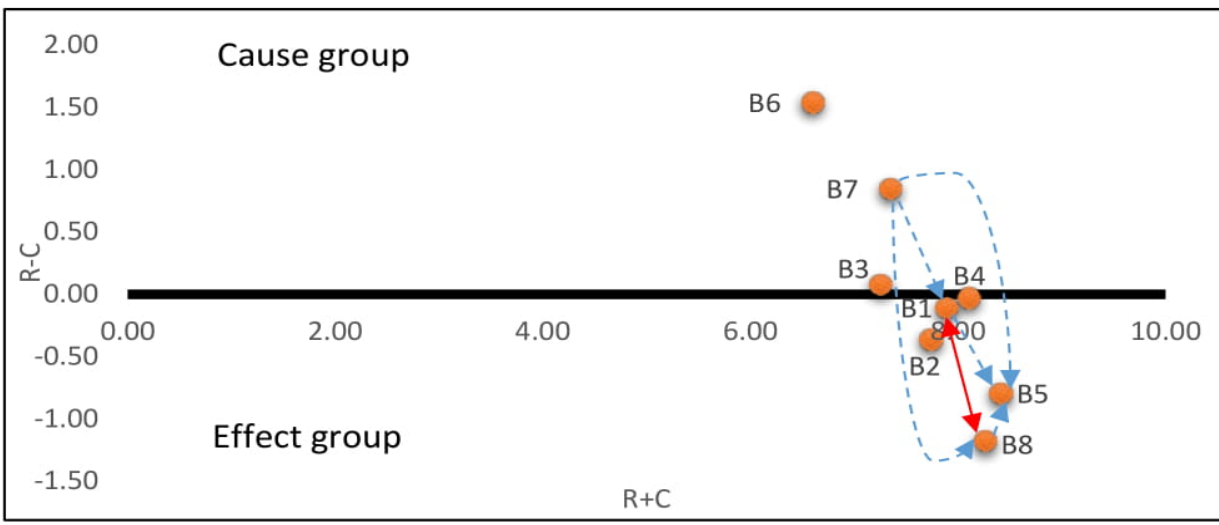

Significant relationships: B1-B5, B1-B8, B7-B1, B7-B5, B7-B8, B8-B5

d) Government officials

Figure 3: DEMATEL prominence-causal relationship diagrams 
Table 8 summarizes the overall results and highlights the barriers assigned the highest prominence values and net causal-effect values across the four evaluating groups. This research considered a barrier as a key cause or prominent barrier only if the same is reflected from the results of at least three evaluator groups. Therefore, weak environmental regulations and enforcement (B6) and lack of market preference/pressure (B7) are identified as key cause barriers, whereas, lack of collaboration/support from supply chain actors (B8) is identified as the only prominent barrier under the established criteria. To our surprise, the prominent barriers and key cause barriers are obviously different from barriers rankings based on the evaluator's importance rankings across the three groups (see Table 7). This suggests that the really important barriers, namely the prominent and key cause barriers, are quite different from the ones perceived by the evaluators.

Table 8: Barriers with the highest prominence and net cause-effect values

\begin{tabular}{lll}
\hline Barriers & Prominence & Net-cause \\
\hline B1: Lack of financial resources & \\
B2: Limited expertise, technology, and information & \\
B3: Organizational culture and management & \\
B4: Uncertainty about benefits & \\
B5: Lack of economies of scale & \\
B6: Weak environmental regulations and & All stakeholders \\
enforcement & \\
B7: Lack of market preference/pressure & All Stakeholders \\
$\begin{array}{l}\text { B8: Lack of collaboration/support from supply } \\
\text { chain actors }\end{array}$ & $\begin{array}{l}\text { Food processors, } \\
\text { Sales \& distribution } \\
\text { channels, and } \\
\text { Customers }\end{array}$ \\
\hline $\begin{array}{l}\text { Note: Barriers highlighted in bold have the highest prominence/net cause-effect values rated by at least three } \\
\text { evaluator groups }\end{array}$
\end{tabular}




\section{Discussion}

\subsection{Theoretical contributions}

This paper makes multiple theoretical contributions to supply chain sustainability research. Firstly, it establishes circular supply chain as a new frontier in supply chain sustainability research and practice. Circular supply chain's zero-waste vision is not only inspirational, but also achievable by restorative and regenerative design to achieve circularity of materials through system-wide innovations. In the context of food sector, this study illustrates how a circular food supply chain differs from a linear (traditional) food supply chain.

Secondly, this research develops a theoretical framework of barriers to integrating CE in SCM, using multiple organizational theories. The framework is not only based on literature but also refined and validated based on inputs from experienced food supply chain professionals, government officials, and academic researchers. The general applicability of the framework is demonstrated in a quantitative study of barriers to circular food supply chains in China using the fuzzy DEMATEL technique.

Thirdly, the DEMATEL analysis results show that resource dependence theory (Pfeffer and Salancik, 2003) is most relevant for explaining the prominent barrier(s), while institutional theory and stakeholder theory is most relevant for the key cause barriers. Specifically, the most prominent barrier B8 (lack of collaboration/support from supply chain actors) which requires immediate intervention is linked with resource dependence theory. In the extant literature, resource dependence theory has broadly been applied across the research domains for more than three decades to explain how organizations reduce environmental interdependence and uncertainty (Hillman et al., 2009). B6 (weak environmental regulations and enforcement) and B7 (lack of market preference/pressure) being the most significant cause barriers are grounded in institutional theory and stakeholder theory. Institutional theory has risen to prominence as a 
popular and powerful theory offering an explanation for organizational actions (Dacin et al., 2002), especially with regards to supply chain sustainability issues (Zhu et al., 2011). Pressures from stakeholders and institutions are taken seriously by many firms, and they necessitate proactive sustainability strategies (Tate et al., 2010).

Fourthly, the results suggest the barriers derived from the RBV, dynamic capabilities theory, and contingency theory are overall less significant in integrating CE in the Chinese food supply chains. This does not mean that these theories are not relevant or invalid, but only suggest they have relatively limited power for explaining the concerned organizational behaviors in the context of the Chinese food supply chains. A possible explanation of this finding is that the $\mathrm{RBV}$, dynamic capabilities theory and contingency theory were developed primarily for explaining organizations' competitive advantage in economic performance (Barney, 1991, Teece et al., 1997, Gulati and Sytch, 2007), rather than in environmental sustainability performance. Further research studies are required to deepen our understanding on the applicability of these theories for explaining organizational behaviors in sustainability-related practices.

Finally, it is interesting to find out that the key barriers revealed by the DEMATEL analysis are quite different from the ones rated by the evaluators based on their importance rankings (Table 7). This shows that the results are non-intuitive. Therefore, it is essential to employ a scientific prioritization technique like fuzzy DEMATEL to uncover the hidden causal-effect relationships among barriers. These identified causal-effect relationships can be used as a reference for future empirical investigations.

\subsection{Practical implications of prominent barrier(s)}

This study focuses on different stakeholders of food supply chains in China. Taking a broader perspective to discuss the relevance of the results at a supply chain level, we first discuss the 
barrier(s) with the highest prominence value(s), as they have the potential to affect and/or be affected by other barriers therefore, managers and policy makers should prioritize addressing or circumventing these in the short run. B8 (Lack of collaboration/support from supply chain actors) has the highest prominence value.

As discussed earlier, the implementation of $\mathrm{CE}$ is costly and affects various supply chain functions. $\mathrm{CE}$ in the food sector implies the use of more natural and organic ingredients in growing/farming as well as processing and manufacturing stages. To decrease the packaging waste, $\mathrm{CE}$ implies the use of environmentally friendly biodegradable packaging materials. In manufacturing, $\mathrm{CE}$ requires the implementation of cleaner production technologies to conserve energy and reduce waste and emissions. Logistics implications include the design of green and efficient logistics networks for forward and reverse product flows. Moreover, on the consumption side, customer and public participation in CE is critically important for the endof-life management of leftovers; of unwanted, expired or waste food; and packaging materials for resource recovery purposes. In this regard, collection and processing of the waste streams could be quite challenging at supply chain level. It is therefore unsurprising to see lack of collaboration/support from supply chain actors (B8) as the most prominent barrier to successful implementation of CE at supply chain level. This is consistent with Hau lee's Triple A supply chain strategy which suggests that lack of alignment among supply chain partners causes the failure of many supply chain practices (Lee, 2004).

On the other hand, research suggests that the implementation of the CE offer numerous opportunities for organizational gains in supply chains (Govindan and Hasanagic, 2018). For example, in most industries including food sector, many by-products cannot be efficiently reused or recycled within an individual plant, thus, this provides a potential collaboration opportunity with surrounding firms, and this also encourages the establishment and 
maintenance of a formal regional eco-industrial network (Geng and Doberstein, 2008). From a strategic viewpoint, we suggest systemic sustainability collaboration (Nidumolu et al., 2014) among key food supply chain players (food processors, sales and distribution channels and customer) in China with an explicit focus on improving economic and environmental impact outcomes. A recent study by Morone et al. (2019) found a positive impact of collaboration among supply chain member on environmental and financial performance in China. Moreover, improved collaboration between municipal waste management systems and supermarkets/food e-retailers may also be effective to streamline the end-of-life resource recovery and consequently, and to mitigate uncertainties surrounding the economic and environmental benefits of implementing CE. The collaborative arrangement can also be extended to involve external stakeholders such as government, non-governmental organizations, and academicians to stimulate long-term sustainability innovations.

\subsection{Practical implications of key cause barriers}

Barriers with the highest net causal-effect values have the greatest long-term impact on the whole system, so they should be paid more attention. B6 (weak environmental regulations and enforcement) has the highest net causal-effect value. Although China has taken the lead by adopting and promoting $\mathrm{CE}$ as a national policy, enforcement of such environmental regulations has been more problematic than their promulgation, plagued by low bureaucratic status and prevalent corruption (Geng et al., 2010). The NDRC, being mandated to promote $\mathrm{CE}$ across China, needs to develop an effective enforcement mechanism to implement $\mathrm{CE}$ at the micro level. Notably, the CE indicators published by the NDRC have been designed for the macro and meso levels, whereas micro-level indicators are absent (Geng et al., 2012), which affects the promotion of $\mathrm{CE}$ at that level. Su et al. (2013) argue that standardized micro-level indicators may fail to capture CE progress in different firms and industries. However, to ensure 
$\mathrm{CE}$ implementation at the micro level, it is imperative to develop relevant indicators. The NDRC may consider broad standards and indicators for the micro level that can be adapted or tailored by firms to reflect their specific characteristics, conditions, and problems. These indicators should include detailed descriptions, industry-specific goals and standardized procedures for collecting, measuring, and submitting the required data (Geng et al., 2012). More stringent regulatory mechanisms need to be in place for monitoring and enforcing the indicator system. The food industry, along with other industries, should be made acquainted with these indicators to ensure maximum compliance.

The other barrier with a high causal-effect value is B7 (lack of market preference/pressure). In China, most of the policies surrounding environmental initiatives do not involve any public consultation. The absence of any formal institutional structure for this in the Chinese political system as indicated by Geng et al. (2010) further weakens the public interest in and awareness of environmental initiatives such as CE. Borrello et al. (2017) found that appropriate incentivization of food take-back programmes positively affect consumers' participation and commitment in circular loops. We suggest an extensive promotion campaign using media such as internet, social media, TV, radio, and newsletters besides interactive platforms like exhibitions, conferences, and workshops. To sustain the public interest and awareness over the long term, it is essential to incorporate $\mathrm{CE}$ and environmental education in schools.

\subsection{Summary of New Insights and Future Research Directions}

This research provided a multi-stakeholder perspective on barriers to circular food supply chains. The study results offer insights for all stakeholders irrespective of their involvement level whether direct or indirect. This subsection summarizes new insights that were not reported in the extant literature and discuss important research directions for further studies. 
China being the first country in the world to legislate $\mathrm{CE}$ as part of its national development strategy has enacted a series of government driven legislation to push CE implementation. However, weak enforcement of such environmental regulations was found to be a key cause barrier in the food sector. This is ironic and thought-provoking given the Chinese government's stance on CE. The other key cause barrier lies in the issue of most Chinese consumers and businesses caring little about environmental protection; hence a lack of public commitment and support to the government's CE aspiration. These finding have serious implications for policy makers in China to address issues in bureaucracy, governance, corruption and environmental education.

Previous CE related barrier studies focused on the macro and meso level implementation. From a micro perspective, this study identified lack of collaboration/support from supply chain actors as a new barrier not previously reported. The finding is significant because this barrier emerged as the only identified prominent barrier by all three supply chain stakeholders. It provides empirical evidence to Mathews and Tan (2016) claim that the main obstacle to successful implementation of CE in China is getting firms linked by circular supply chains. EIPs as facilitating physical infrastructure have been developed by the Chinese government for achieving the goal, but they do not seem to be enough to stimulate a transformation to circular supply chains. Future research may investigate how to further facilitate and incentivize firms to collaborate to make their supply chains circular. Smart enabling technologies including internet of things (IoT), big data analytics and blockchain have developed rapidly in recent years. Future research may examine their usage and effectiveness in aiding circular supply chain management. There are also ample rooms for researchers to investigate the role of soft infrastructure including rewards and penalty systems, supply chain incentive alignment, product stewardship (Jensen and Remmen, 2017), extended producer responsibility (Kunz et al., 2018), and sustainable product-service system (Kjaer et al., 2018). 
Circular supply chain is a relatively new but promising domain in supply chain sustainability research. We call for more research contributions in this growing field. For many decades, the focus of waste management has been on improving the efficiency and effectiveness of waste management operations. However, such a traditional waste management thinking can never achieve CE's zero-waste vision. In a CE context, waste management requires a much stronger focus on value recovery, i.e., turning waste into resource. Furthermore, CE requires a rethinking of product/service design in order not to generate waste at all wherever possible. More research is required in innovative design of products/services and supporting circular business models and supply chain processes.

Furthermore, circular supply chain barriers are context dependent as behaviour barriers vary by cultures and different product sectors may require a different set of supply chain actors to collaborate for turning waste into resource. In addition, barriers are dynamic as they may evolve over time. Therefore, it is necessary to conduct more circular supply chain barrier studies in other contexts that are different from that of this study. Our theoretical framework may serve as a guide for future studies. Since this barrier study identified three theories being most relevant, namely, resource dependence theory, institutional theory, and stakeholder theory. They can be focused on in broader empirical studies on circular supply chains.

\section{Conclusions}

The rate of China's consumption of global resources and the production of solid waste poses a severe threat to the world's sustainability. To overcome the challenges associated with recirculation of waste materials, the Chinese government has heavily invested in implementing $\mathrm{CE}$ over the last decade. However, the progress has been modest due to obstacles to linking firms in circular supply chains that cooperate to turn outputs into inputs. This study identifies and analyses the specific barriers to integrating CE in SCM in the context of food supply chains 
in China. The severity of adverse environmental impacts of food supply chains and scarcity of research on their sustainability practices make this issue worth investigating.

The first original contribution of this research is in conceptualizing circular food supply chain, in the context of integrating CE philosophy in SCM, a new frontier in supply chain sustainability research and practice. Secondly, this research develops a theoretical framework drawing on multiple organizational theories to identify barriers to integrating CE in SCM. The quantitative analysis results show that resource dependence theory, institutional theory, and stakeholder theory are most relevant for integrating $\mathrm{CE}$ in the Chinese food supply chains. Thirdly, to the best of our knowledge, this is the very first attempt to systematically investigate and prioritize the barriers to circular food supply chains in China. Viewpoints from four evaluating groups (food processors, sales and distribution channels, customer and government officials) were explored. The results suggest weak environmental regulations and enforcement, and lack of market preference/pressure as the key cause barriers. Moreover, lack of collaboration/support from supply chain actors is considered as the most prominent barrier. The results are non-intuitive, which proves the necessity of employing a scientific prioritization technique like fuzzy DEMATEL. Finally, this study discusses theoretical and practical implications for overcoming/circumventing the barriers. It offers new insights for future research directions in supply chain sustainability.

Despite several contributions, this study has its limitations. First, the barriers identified in the study were far from being exhaustive although they were enough for meeting the research objectives. Future studies may expand the list of barriers under most relevant theoretical lenses identified in this study to suit their research objectives. Second, the study analyzed responses from multiple food supply chain stakeholders in China. However, farmers being one of the important food supply chain stakeholders could not be included in the analysis due to data 
quality issue. Last but not the least, the cross-sectional survey design uncovered barriers at a given point in time but were unable to reveal how barriers evolved over time. Future research may consider a longitudinal study for generating more insights.

\section{Disclosure statement}

No potential conflict of interest was reported by the authors. 


\section{References}

Ahi, P. \& Searcy, C., 2015, "An analysis of metrics used to measure performance in green and sustainable supply chains", Journal of Cleaner Production, 86, 360-377.

Aminoff, A. \& Kettunen, O., "Sustainable Supply Chain Management in a Circular Economy-Towards Supply Circles", In: Setchi, R., Howlett, R. J., Liu, Y. \& Theobald, P., ed.^eds. Sustainable Design and Manufacturing, 2016: Springer International Publishing, 61-72.

Aronow, S., Ennis, K. \& Romano, J., 2018, "The Gartner Supply Chain Top 25 for 2018" [Online], Available: https://www.gartner.com/doc/3875506? [Accessed 25 February 2019].

Awasthi, A. K., Cucchiella, F., D'Adamo, I., Li, J., Rosa, P., Terzi, S., Wei, G. \& Zeng, X., 2018, "Modelling the correlations of e-waste quantity with economic increase", Science of The Total Environment, 613-614, 46-53.

Bai, C. \& Sarkis, J., 2013, "A grey-based DEMATEL model for evaluating business process management critical success factors", International Journal of Production Economics, 146, 281-292.

Bai, C., Sarkis, J. \& Dou, Y., 2017, "Constructing a process model for low-carbon supply chain cooperation practices based on the DEMATEL and the NK model", Supply Chain Management: An International Journal, 22, 237-257.

Barney, J., 1991, "Firm Resources and Sustained Competitive Advantage", Journal of Management, 17, 99-120.

Batista, L., Bourlakis, M., Smart, P. \& Maull, R., 2018a, "In search of a circular supply chain archetypea content-analysis-based literature review", Production Planning and Control, 29, 438-451.

Batista, L., Gong, Y., Pereira, S., Jia, F. \& Bittar, A., 2018b, "Circular supply chains in emerging economies-a comparative study of packaging recovery ecosystems in China and Brazil", International Journal of Production Research.

Baykasoğlu, A. \& Gölcük, i., 2015, "Development of a novel multiple-attribute decision making model via fuzzy cognitive maps and hierarchical fuzzy TOPSIS", Information Sciences, 301, 75-98.

Bernon, M., Tjahjono, B. \& Ripanti, E. F., 2018, "Aligning retail reverse logistics practice with circular economy values: an exploratory framework", Production Planning and Control, 29, 483-497.

Bicket, M., Guilcher, S., Hestin, M., Hudson, C., Razzini, P., Tan, A., ten Brink, P., van Dijl, E., Vanner, R. \& Watkins, E., 2014, "Scoping study to identify potential circular economy actions, priority sectors, material flows and value chains", Available: http://bookshop.europa.eu/en/scopingstudy-to-identify-potential-circular-economy-actions-priority-sectors-material-flows-andvalue-chains-pbKH0114775/.

Borrello, M., Caracciolo, F., Lombardi, A., Pascucci, S. \& Cembalo, L., 2017, "Consumers' Perspective on Circular Economy Strategy for Reducing Food Waste", Sustainability, 9, 141.

Borrello, M., Lombardi, A., Pascucci, S. \& Cembalo, L., 2016, "The Seven Challenges for Transitioning into a Bio-based Circular Economy in the Agri-food Sector", Recent Patents on Food, Nutrition \& Agriculture, $8,39-47$.

Bressanelli, G., Perona, M. \& Saccani, N., 2018, "Challenges in supply chain redesign for the Circular Economy: a literature review and a multiple case study", International Journal of Production Research.

Brundtland, G. H., 1987, "World commission on environment and development (1987): Our common future", World Commission for Environment and Development.

Buysse, K. \& Verbeke, A., 2003, "Proactive environmental strategies: A stakeholder management perspective", Strategic management journal, 24, 453-470.

Büyüközkan, G. \& Güleryüz, S., 2016, "An integrated DEMATEL-ANP approach for renewable energy resources selection in Turkey", International Journal of Production Economics, 182, 435-448.

Carter, R. C. \& Dale, S. R., 2008, "A framework of sustainable supply chain management: moving toward new theory", International Journal of Physical Distribution \& Logistics Management, 38, 360-387.

Cui, K. \& Shoemaker, S. P., 2018, "A look at food security in China", npj Science of Food, 2, 4. 
Dacin, M. T., Goodstein, J. \& Scott, W. R., 2002, "Institutional Theory and Institutional Change: Introduction to the Special Research Forum", The Academy of Management Journal, 45, 4556.

Daily, B. F. \& Huang, S. C., 2001, "Achieving sustainability through attention to human resource factors in environmental management", International Journal of Operations \& Production Management, 21, 1539-1552.

De Angelis, R., Howard, M. \& Miemczyk, J., 2018, "Supply chain management and the circular economy: towards the circular supply chain", Production Planning and Control, 29, 425-437.

DiMaggio, P. J. \& Powell, W. W., 1983, "The Iron Cage Revisited: Institutional Isomorphism and Collective Rationality in Organizational Fields", American Sociological Review, 48, 147-160.

Donaldson, T. \& Preston, L. E., 1995, "The Stakeholder Theory of the Corporation: Concepts, Evidence, and Implications", Academy of Management Review, 20, 65-91.

Dou, Y., Sarkis, J. \& Bai, C., "Government Green Procurement: A Fuzzy-DEMATEL Analysis of Barriers", In: Kahraman, C. \& Öztayşi, B., ed.^eds. Supply Chain Management Under Fuzziness: Recent Developments and Techniques, 2014 Berlin, Heidelberg: Springer Berlin Heidelberg, 567-589.

Eisenhardt, K. M. \& Martin, J. A., 2000, "Dynamic Capabilities: What Are They?", Strategic Management Journal, 21, 1105-1121.

EMF (Ellen MacArthur Foundation), 2012, "Towards the circular economy" [Online], Available: https://www.ellenmacarthurfoundation.org/publications/towards-the-circular-economyvol-1-an-economic-and-business-rationale-for-an-accelerated-transition [Accessed 13/02/2018].

EMF (Ellen MacArthur Foundation), 2013, "Towards the Circular Economy: Economic and Business Rationale for an Accelerated Transition" [Online], Available: https://www.ellenmacarthurfoundation.org/assets/downloads/publications/EllenMacArthur-Foundation-Towards-the-Circular-Economy-vol.1.pdf [Accessed 13/02/2018].

EMF (Ellen MacArthur Foundation), 2014, "Towards the circular economy: Accelerating the scale-up across global supply [Online], Available: https://www.ellenmacarthurfoundation.org/assets/downloads/publications/Towards-thecircular-economy-volume-3.pdf [Accessed 13/02/2018].

Fang, Y., Côté, R. P. \& Qin, R., 2007, "Industrial sustainability in China: Practice and prospects for ecoindustrial development", Journal of Environmental Management, 83, 315-328.

FAO (Food and Agricultural Organisation), 2011, "Food Loss and Food Waste" [Online], Available: http://www.fao.org/food-loss-and-food-waste/en/ [Accessed 28/03/2018].

FAO (Food and Agricultural Organisation), 2015, "Food wastage footprint \& climate change" [Online]: Food and Agricultural Organisation of United Nations, Available: http://www.fao.org/3/abb144e.pdf [Accessed 13/02/2019].

Farooque, M. \& Zhang, A., "Supply chain management for the circular economy: A review and a classification of terms. ", In: Castka, P., Wilson, M. M. J. \& Chowdhury, M., ed.^eds. Proceedings of the 15th ANZAM Operations, Supply Chain and Services Management Symposium, 2017, 9-10.

Finkelstein, S., 1997, "Interindustry Merger Patterns and Resource Dependence: A Replication and Extension of Pfeffer (1972)", Strategic Management Journal, 18, 787-810.

Freeman, R. E., 2010, Strategic management: A stakeholder approach, Cambridge university press.

$\mathrm{Fu}$, X., Zhu, Q. \& Sarkis, J., 2012, "Evaluating green supplier development programs at a telecommunications systems provider", International Journal of Production Economics, 140, 357-367.

Gandhi, S., Mangla, S. K., Kumar, P. \& Kumar, D., 2015, "Evaluating factors in implementation of successful green supply chain management using DEMATEL: A case study", International Strategic Management Review, 3, 96-109. 
Geng, Y. \& Doberstein, B., 2008, "Developing the circular economy in China: Challenges and opportunities for achieving 'leapfrog development'", International Journal of Sustainable Development \& World Ecology, 15, 231-239.

Geng, Y., Fu, J., Sarkis, J. \& Xue, B., 2012, "Towards a national circular economy indicator system in China: an evaluation and critical analysis", Journal of Cleaner Production, 23, 216-224.

Geng, Y., Sarkis, J., Ulgiati, S. \& Zhang, P., 2013, "Measuring China's Circular Economy", Science, 339, 1526-1527.

Geng, Y., Xinbei, W., Qinghua, Z. \& Hengxin, Z., 2010, "Regional initiatives on promoting cleaner production in China: a case of Liaoning", Journal of Cleaner Production, 18, 1502-1508.

Geng, Y., Zhu, Q., Doberstein, B. \& Fujita, T., 2009, "Implementing China's circular economy concept at the regional level: A review of progress in Dalian, China", Waste Management, 29, 9961002.

Genovese, A., Acquaye, A. A., Figueroa, A. \& Koh, S. C. L., 2017, "Sustainable supply chain management and the transition towards a circular economy: Evidence and some applications", Omega, 66, 344-357.

Ghisellini, P., Cialani, C. \& Ulgiati, S., 2016, "A review on circular economy: the expected transition to a balanced interplay of environmental and economic systems", Journal of Cleaner Production, 114, 11-32.

Giunipero, L. C., Hooker, R. E. \& Denslow, D., 2012, "Purchasing and supply management sustainability: Drivers and barriers", Journal of Purchasing and Supply Management, 18, 258-269.

Govindan, K., Diabat, A. \& Madan Shankar, K., 2015a, "Analyzing the drivers of green manufacturing with fuzzy approach", Journal of Cleaner Production, 96, 182-193.

Govindan, K. \& Hasanagic, M., 2018, "A systematic review on drivers, barriers, and practices towards circular economy: a supply chain perspective", International Journal of Production Research, 56, 278-311.

Govindan, K., Kannan, D. \& Shankar, M., 2015b, "Evaluation of green manufacturing practices using a hybrid MCDM model combining DANP with PROMETHEE", International Journal of Production Research, 53, 6344-6371.

Govindan, K. \& Soleimani, H., 2017, "A review of reverse logistics and closed-loop supply chains: a Journal of Cleaner Production focus", Journal of Cleaner Production, 142, 371-384.

Guide, V. D. R. \& Ketokivi, M., 2015, "Notes from the Editors: Redefining some methodological criteria for the journal", Journal of Operations Management, 37, v-viii.

Guide, V. D. R. \& Van Wassenhove, L. N., 2006, "Closed-Loop Supply Chains: An Introduction to the Feature Issue (Part 1)", Production and Operations Management, 15, 345-350.

Gulati, R. \& Sytch, M., 2007, "Dependence Asymmetry and Joint Dependence in Interorganizational Relationships: Effects of Embeddedness on a Manufacturer's Performance in Procurement Relationships", Administrative Science Quarterly, 52, 32-69.

Gurtu, A., Searcy, C. \& Jaber, M., 2015, "An analysis of keywords used in the literature on green supply chain management", Management Research Review, 38, 166-194.

Hillman, A. J., Withers, M. C. \& Collins, B. J., 2009, "Resource Dependence Theory: A Review", Journal of Management, 35, 1404-1427.

Hobson, K., 2016, "Closing the loop or squaring the circle? Locating generative spaces for the circular economy", Progress in Human Geography, 40, 88-104.

Hoornweg, D., Bhada-Tata, P. \& Kennedy, C., 2013, "Environment: Waste production must peak this century", Nature, 502, 615-7.

Hsu, C.-C., Choon Tan, K., Hanim Mohamad Zailani, S. \& Jayaraman, V., 2013, "Supply chain drivers that foster the development of green initiatives in an emerging economy", International Journal of Operations \& Production Management, 33, 656-688.

Hu, H.-Y., Chiu, S.-I., Cheng, C.-C. \& Yen, T.-M., 2011, "Applying the IPA and DEMATEL models to improve the order-winner criteria: A case study of Taiwan's network communication equipment manufacturing industry", Expert Systems with Applications, 38, 9674-9683. 
Jennings, P. D. \& Zandbergen, P. A., 1995, "Ecologically Sustainable Organizations: An Institutional Approach", Academy of Management Review, 20, 1015-1052.

Jensen, J. P. \& Remmen, A., 2017, "Enabling Circular Economy Through Product Stewardship", Procedia Manufacturing, 8, 377-384.

Jurgilevich, A., Birge, T., Kentala-Lehtonen, J., Korhonen-Kurki, K., Pietikäinen, J., Saikku, L. \& Schösler, H., 2016, "Transition towards Circular Economy in the Food System", Sustainability, 8, 69.

Kaur, J., Sidhu, R., Awasthi, A., Chauhan, S. \& Goyal, S., 2017, "A DEMATEL based approach for investigating barriers in green supply chain management in Canadian manufacturing firms", International Journal of Production Research, 1-21.

Kazancoglu, Y., Kazancoglu, I. \& Sagnak, M., 2018, "A new holistic conceptual framework for green supply chain management performance assessment based on circular economy", Journal of Cleaner Production, 195, 1282-1299.

Kjaer, L. L., Pigosso, D. C. A., Niero, M., Bech, N. M. \& McAloone, T. C., 2018, "Product/Service-Systems for a Circular Economy: The Route to Decoupling Economic Growth from Resource Consumption?", Journal of Industrial Ecology, 23, 22-35.

Kumar, A. \& Dixit, G., 2018, "An analysis of barriers affecting the implementation of e-waste management practices in India: A novel ISM-DEMATEL approach", Sustainable Production and Consumption, 14, 36-52.

Kunz, N., Mayers, K. \& Van Wassenhove, L. N., 2018, "Stakeholder Views on Extended Producer Responsibility and the Circular Economy", California Management Review, 60, 45-70.

Lapko, Y., Trianni, A., Nuur, C. \& Masi, D., 2018, "In Pursuit of Closed-Loop Supply Chains for Critical Materials: An Exploratory Study in the Green Energy Sector", Journal of Industrial Ecology, 23, 182-196.

Larsen, S. B., Masi, D., Jacobsen, P. \& Godsell, J., 2018, "How the reverse supply chain contributes to a firm's competitive strategy: a strategic alignment perspective", Production Planning and Control, 29, 452-463.

Lawrence, P. R. \& Lorsch, J. W., 1967, "Differentiation and Integration in Complex Organizations", Administrative Science Quarterly, 12, 1-47.

Lawson, B. \& Samson, D., 2001, "Developing innovation capability in organisations: A dynamic capabilities approach", International Journal of Innovation Management, 05, 377-400.

Lee, H. L., 2004, "The triple-A supply chain", Harvard business review, 82, 102-113.

Lin, R.-J., 2013, "Using fuzzy DEMATEL to evaluate the green supply chain management practices", Journal of Cleaner Production, 40, 32-39.

Liu, G., 2014, "Food Losses and Food Waste in China", OECD Food, Agriculture and Fisheries Papers [Online], 66, Available: https://www.oecd-ilibrary.org/content/paper/5jz5sq5173lq-en.

Liu, G., Liu, X. \& Cheng, S., 2013, "Food security: Curb China's rising food wastage", Nature, 498, 170.

Liu, J., Feng, Y., Zhu, Q. \& Sarkis, J., 2018, "Green supply chain management and the circular economy: Reviewing theory for advancement of both fields", International Journal of Physical Distribution and Logistics Management, 48, 794-817.

Malviya, R. K. \& Ravi, K., 2015, "Green supply chain management (GSCM): a structured literature review and research implications", Benchmarking: An International Journal, 22, 1360-1394.

Mangla, S. K., Luthra, S., Mishra, N., Singh, A., Rana, N. P., Dora, M. \& Dwivedi, Y., 2018, "Barriers to effective circular supply chain management in a developing country context", Production Planning \& Control, 29, 551-569.

Masi, D., Day, S. \& Godsell, J., 2017, "Supply chain configurations in the circular economy: A systematic literature review", Sustainability (Switzerland), 9, 1602.

Mathews, J. A. \& Tan, H., 2016, "Circular economy: Lessons from China", Nature, 531, 440-2.

Miller, D., 1987, "The structural and environmental correlates of business strategy", Strategic Management Journal, 8, 55-76.

Mirabella, N., Castellani, V. \& Sala, S., 2014, "Current options for the valorization of food manufacturing waste: a review", Journal of Cleaner Production, 65, 28-41. 
Mishra, J. L., Hopkinson, P. G. \& Tidridge, G., 2018, "Value creation from circular economy-led closed loop supply chains: a case study of fast-moving consumer goods", Production Planning and Control, 29, 509-521.

Morone, P., Falcone, P. M. \& Lopolito, A., 2019, "How to promote a new and sustainable food consumption model: A fuzzy cognitive map study", Journal of Cleaner Production, 208, 563574.

Mylan, J., Holmes, H. \& Paddock, J., 2016, "Re-Introducing Consumption to the 'Circular Economy': A Sociotechnical Analysis of Domestic Food Provisioning", Sustainability, 8, 794.

Nasir, M. H. A., Genovese, A., Acquaye, A. A., Koh, S. C. L. \& Yamoah, F., 2017, "Comparing linear and circular supply chains: A case study from the construction industry", International Journal of Production Economics, 183, 443-457.

Ness, D., 2008, "Sustainable urban infrastructure in China: Towards a Factor 10 improvement in resource productivity through integrated infrastructure systems", International Journal of Sustainable Development \& World Ecology, 15, 288-301.

Nidumolu, R., Ellison, J., Whalen, J. \& Billman, E., 2014, "The collaboration imperative", Harvard business review, 92, 76-84, 132.

North, D. C., 1990, Institutions, institutional change and economic performance, Cambridge university press.

NRDC (National Development and Reform Commission), 2017, "Notice of the Evaluation Index System for the Development of Circular Economy" [Online], Available: http://www.ndrc.gov.cn/zcfb/zcfbtz/201701/t20170112 834922.html [Accessed 16 July 2018. (In Chinese)].

Petljak, K., Zulauf, K., Štulec, I., Seuring, S. \& Wagner, R., 2018, "Green supply chain management in food retailing: survey-based evidence in Croatia", Supply Chain Management: An International Journal, 23, 1-15.

Pfeffer, J., 1972, "Merger as a Response to Organizational Interdependence", Administrative Science Quarterly, 17, 382-394.

Pfeffer, J. \& Pfeffer, J., 1981, Power in organizations, Pitman Marshfield, MA.

Pfeffer, J. \& Salancik, G. R., 2003, The external control of organizations: A resource dependence perspective, Stanford University Press.

Rauer, J. \& Kaufmann, L., 2015, "Mitigating External Barriers to Implementing Green Supply Chain Management: A Grounded Theory Investigation of Green-Tech Companies' Rare Earth Metals Supply Chains", Journal of Supply Chain Management, 51, 65-88.

Rugman, A. M. \& Verbeke, A., 2002, "Edith Penrose's contribution to the resource-based view of strategic management", Strategic Management Journal, 23, 769-780.

Saaty, T. L. 2013, Analytic hierarchy process, In: Gass S.I. \& Fu, M. C. (ed.)^(eds.) Encyclopedia of operations research and management science, ed, Boston, MA Springer.

Sarkis, J., Gonzalez-Torre, P. \& Adenso-Diaz, B., 2010, "Stakeholder pressure and the adoption of environmental practices: The mediating effect of training", Journal of Operations Management, 28, 163-176.

Seuring, S. \& Müller, M., 2008, "From a literature review to a conceptual framework for sustainable supply chain management", Journal of Cleaner Production, 16, 1699-1710.

Shao, J., Taisch, M. \& Ortega-Mier, M., 2016, "A grey-DEcision-MAking Trial and Evaluation Laboratory (DEMATEL) analysis on the barriers between environmentally friendly products and consumers: practitioners' viewpoints on the European automobile industry", Journal of Cleaner Production, 112, 3185-3194.

Shenoy, M. 2016, Industrial Ecology in Developing Countries, In: Clift, R. \& Druckman, A. (ed.)^(eds.) Taking Stock of Industrial Ecology, ed, Cham: Springer International Publishing.

Shi, H., Peng, S. Z., Liu, Y. \& Zhong, P., 2008, "Barriers to the implementation of cleaner production in Chinese SMEs: government, industry and expert stakeholders' perspectives", Journal of Cleaner Production, 16, 842-852. 
Srivastava, S. K., 2007, "Green supply-chain management: A state-of-the-art literature review", International Journal of Management Reviews, 9, 53-80.

Stahel, W. R., 2016, "The circular economy", Nature, 531, 435-8.

Stenmarck, A.., Jensen, C., Quested, T. \& Moates, G. 2016. Estimates of European food waste levels. Stockholm: European Commission.

Stone, J. \& Rahimifard, S., 2018, "Resilience in agri-food supply chains: a critical analysis of the literature and synthesis of a novel framework", Supply Chain Management: An International Journal, 23, 207-238.

Su, B., Heshmati, A., Geng, Y. \& Yu, X., 2013, "A review of the circular economy in China: moving from rhetoric to implementation", Journal of Cleaner Production, 42, 215-227.

Tai, J., Zhang, W., Che, Y. \& Feng, D., 2011, "Municipal solid waste source-separated collection in China: A comparative analysis", Waste Management, 31, 1673-1682.

Tate, W. L., Ellram, L. M. \& Kirchoff, J. F., 2010, "Corporate social responsibility reports: a thematic analysis related to supply chain management", Journal of Supply Chain Management, 46, 1944.

Teece, D. J., Pisano, G. \& Shuen, A., 1997, "Dynamic capabilities and strategic management", Strategic Management Journal, 18, 509-533.

Thompson, J. D., 1967, Organizations in action: Social science bases of administrative theory, Transaction publishers.

Touboulic, A., Matthews, L. \& Marques, L., 2018, "On the road to carbon reduction in a food supply network: a complex adaptive systems perspective", Supply Chain Management: An International Journal, 23, 313-335.

Tseng, M.-L., Wang, R., Chiu, A. S. F., Geng, Y. \& Lin, Y. H., 2013, "Improving performance of green innovation practices under uncertainty", Journal of Cleaner Production, 40, 71-82.

Tura, N., Hanski, J., Ahola, T., Ståhle, M., Piiparinen, S. \& Valkokari, P., 2019, "Unlocking circular business: A framework of barriers and drivers", Journal of Cleaner Production, 212, 90-98.

Veleva, V., Bodkin, G. \& Todorova, S., 2017, "The need for better measurement and employee engagement to advance a circular economy: Lessons from Biogen's "zero waste" journey", Journal of Cleaner Production, 154, 517-529.

Venkatesh, V. G., Zhang, A., Luthra, S., Dubey, R., Subramanian, N. \& Mangla, S., 2017, "Barriers to coastal shipping development: An Indian perspective", Transportation Research Part D: Transport and Environment, 52, 362-378.

Vickerson, A., 2016, "Circular economy: Getting the circulation going", Nature, 531, 443.

Vujanović, D., Momčilović, V., Bojović, N. \& Papić, V., 2012, "Evaluation of vehicle fleet maintenance management indicators by application of DEMATEL and ANP", Expert Systems with Applications, 39, 10552-10563.

Walker, H., Di Sisto, L. \& McBain, D., 2008, "Drivers and barriers to environmental supply chain management practices: Lessons from the public and private sectors", Journal of Purchasing and Supply Management, 14, 69-85.

Winkler, H., 2011, "Closed-loop production systems-A sustainable supply chain approach", CIRP Journal of Manufacturing Science and Technology, 4, 243-246.

Wu, W.-W., 2012, "Segmenting critical factors for successful knowledge management implementation using the fuzzy DEMATEL method", Applied Soft Computing, 12, 527-535.

Wu, W.-W. \& Lee, Y.-T., 2007, "Developing global managers' competencies using the fuzzy DEMATEL method", Expert Systems with Applications, 32, 499-507.

Yin, R. K., 2013, Case study research: Design and methods, Sage publications.

Ying, J. \& Li-jun, Z., 2012, "Study on Green Supply Chain Management Based on Circular Economy", Physics Procedia, 25, 1682-1688.

Yu, F., Han, F. \& Cui, Z., 2015, "Evolution of industrial symbiosis in an eco-industrial park in China", Journal of Cleaner Production, 87, 339-347. 
Yuan, Z., Bi, J. \& Moriguichi, Y., 2006, "The Circular Economy: A New Development Strategy in China", Journal of Industrial Ecology, 10, 4-8.

Zeng, H., Chen, X., Xiao, X. \& Zhou, Z., 2017, "Institutional pressures, sustainable supply chain management, and circular economy capability: Empirical evidence from Chinese ecoindustrial park firms", Journal of Cleaner Production, 155, 54-65.

Zhijun, F. \& Nailing, Y., 2007, "Putting a circular economy into practice in China", Sustainability Science, 2, 95-101.

Zhu, Q. \& Sarkis, J., 2007, "The moderating effects of institutional pressures on emergent green supply chain practices and performance", International Journal of Production Research, 45, 43334355.

Zhu, Q., Sarkis, J. \& Lai, K.-h., 2011, "An institutional theoretic investigation on the links between internationalization of Chinese manufacturers and their environmental supply chain management", Resources, Conservation and Recycling, 55, 623-630.

Zhu, Q., Sarkis, J. \& Lai, K.-h., 2013, "Institutional-based antecedents and performance outcomes of internal and external green supply chain management practices", Journal of Purchasing and Supply Management, 19, 106-117.

Zhu, Q., Sarkis, J. \& Lai, K.-h., 2014, "Supply chain-based barriers for truck-engine remanufacturing in China", Transportation Research Part E: Logistics and Transportation Review, 68, 103-117.

Zsidisin, G. A. \& Siferd, S. P., 2001, "Environmental purchasing: a framework for theory development", European Journal of Purchasing \& Supply Management, 7, 61-73. 


\section{Appendix A}

Details of evaluators

\begin{tabular}{|c|c|c|}
\hline Product Type & Frequency & Percentage \\
\hline Flour & 5 & $16 \%$ \\
\hline Beverage & 4 & $13 \%$ \\
\hline Confectionery & 4 & $13 \%$ \\
\hline Dairy & 4 & $13 \%$ \\
\hline Meat & 4 & $13 \%$ \\
\hline Liquor & 2 & $6 \%$ \\
\hline Others* & 9 & $28 \%$ \\
\hline Annual Revenue** (million RMB) & Frequency & Percentage \\
\hline $1-4.9$ & 1 & $2 \%$ \\
\hline $5-9.9$ & 10 & $17 \%$ \\
\hline $10-49.9$ & 10 & $17 \%$ \\
\hline $50-100$ & 11 & $19 \%$ \\
\hline $100-300$ & 8 & $14 \%$ \\
\hline$>300$ & 18 & $31 \%$ \\
\hline Overall industry experience*** & Frequency & Percentage \\
\hline $1-3$ years & 2 & $3 \%$ \\
\hline 4-7 years & 22 & $31 \%$ \\
\hline $8-12$ years & 32 & $46 \%$ \\
\hline Over 13 years & 14 & $20 \%$ \\
\hline Designation*** (Management level) & Frequency & Percentage \\
\hline Mid-level & 27 & $39 \%$ \\
\hline Top-level & 43 & $61 \%$ \\
\hline \multicolumn{3}{|c|}{$\begin{array}{l}\text { *one respondents each (Cereal, Edible Oil, Eggs, Fast food, Frozen } \\
\text { food, Sauces, Seeds, Tea, Water) }\end{array}$} \\
\hline \multicolumn{3}{|c|}{$\begin{array}{l}* * \text { excluding government officials, customers \& unreported } \\
* * * \text { excluding customers }\end{array}$} \\
\hline
\end{tabular}

\section{Appendix B}

An example of pairwise comparison and importance ranking

\begin{tabular}{cccccccccc}
\hline $\begin{array}{c}\text { Evaluators' } \\
\begin{array}{c}\text { importance } \\
\text { ranking }\end{array}\end{array}$ & Barrier & B1 & B2 & B3 & B4 & B5 & B6 & B7 & B8 \\
\cline { 2 - 10 }$y$ & B1 & 0 & 1 & 0 & 0 & 0 & 0 & 0 & 4 \\
4 & B2 & 1 & 0 & 0 & 4 & 4 & 2 & 0 & 0 \\
3 & B3 & 1 & 1 & 0 & 4 & 4 & 2 & 0 & 0 \\
1 & B4 & 1 & 4 & 0 & 0 & 4 & 4 & 4 & 4 \\
2 & B5 & 1 & 2 & 0 & 4 & 0 & 2 & 2 & 0 \\
7 & B6 & 0 & 0 & 0 & 4 & 4 & 0 & 2 & 0 \\
6 & B7 & 1 & 0 & 0 & 4 & 2 & 2 & 0 & 2 \\
5 & B8 & 1 & 0 & 0 & 4 & 4 & 2 & 2 & 0 \\
\hline
\end{tabular}

Note: Evaluators' importance ranking ranges from highest rank (1) to lowest rank (8).

For pairwise comparison, 0 = no Influence, $1=$ very low Influence, $2=$ low Influence, $3=$ high Influence, $4=$ very high Influence 


\section{Appendix C}

The total direct relation matrices $(\mathrm{T})$

Food processors

\begin{tabular}{ccccccccc}
\hline Barrier & B1 & B2 & B3 & B4 & B5 & B6 & B7 & B8 \\
\hline B1 & 0.79 & $\mathbf{0 . 9 5}$ & 0.86 & 0.81 & 0.73 & 0.74 & 0.71 & $\mathbf{0 . 9 8}$ \\
B2 & 0.90 & 0.81 & 0.87 & 0.81 & 0.74 & 0.73 & 0.71 & $\mathbf{0 . 9 8}$ \\
B3 & 0.84 & 0.87 & 0.73 & 0.79 & 0.72 & 0.72 & 0.68 & $\mathbf{0 . 9 3}$ \\
B4 & 0.84 & 0.86 & 0.80 & 0.67 & 0.68 & 0.69 & 0.68 & 0.90 \\
B5 & 0.88 & $\mathbf{0 . 9 1}$ & 0.86 & 0.80 & 0.64 & 0.75 & 0.70 & $\mathbf{0 . 9 3}$ \\
B6 & 0.81 & 0.84 & 0.78 & 0.73 & 0.68 & 0.59 & 0.65 & 0.86 \\
B7 & 0.88 & 0.90 & 0.85 & 0.82 & 0.73 & 0.73 & 0.62 & $\mathbf{0 . 9 2}$ \\
B8 & $\mathbf{0 . 9 8}$ & $\mathbf{1 . 0 2}$ & $\mathbf{0 . 9 4}$ & 0.88 & 0.79 & 0.78 & 0.79 & $\mathbf{0 . 9 1}$ \\
\hline
\end{tabular}

Sales and distribution channels

\begin{tabular}{cccccccccc}
\hline Barrier & B1 & B2 & B3 & B4 & B5 & B6 & B7 & B8 \\
\hline B1 & 1.43 & 1.59 & 1.59 & 1.55 & 1.46 & 1.57 & $\mathbf{1 . 6 9}$ & $\mathbf{1 . 7 0}$ \\
B2 & 1.38 & 1.33 & 1.44 & 1.44 & 1.32 & 1.42 & 1.54 & 1.52 \\
B3 & 1.62 & 1.64 & 1.55 & 1.64 & 1.54 & $\mathbf{1 . 6 6}$ & $\mathbf{1 . 7 9}$ & $\mathbf{1 . 7 6}$ & $\emptyset=1.64$ \\
B4 & 1.46 & 1.53 & 1.51 & 1.39 & 1.40 & 1.49 & 1.63 & 1.59 & \\
B5 & 1.48 & 1.50 & 1.53 & 1.50 & 1.31 & 1.51 & 1.64 & 1.59 & \\
B6 & 1.54 & 1.57 & 1.58 & 1.55 & 1.47 & 1.46 & $\mathbf{1 . 6 9}$ & $\mathbf{1 . 6 7}$ \\
B7 & 1.45 & 1.48 & 1.50 & 1.48 & 1.39 & 1.49 & 1.49 & 1.58 \\
B8 & 1.56 & 1.60 & 1.60 & 1.59 & 1.49 & 1.60 & $\mathbf{1 . 7 3}$ & 1.58 \\
\hline
\end{tabular}

Customers

\begin{tabular}{cccccccccc}
\hline Barrier & B1 & B2 & B3 & B4 & B5 & B6 & B7 & B8 \\
\hline B1 & 0.42 & 0.56 & 0.52 & 0.47 & 0.32 & 0.40 & $\mathbf{0 . 5 9}$ & $\mathbf{0 . 6 2}$ \\
B2 & 0.49 & 0.40 & 0.52 & 0.45 & 0.31 & 0.38 & 0.57 & 0.56 \\
B3 & 0.56 & 0.52 & 0.44 & 0.47 & 0.33 & 0.44 & $\mathbf{0 . 6 4}$ & $\mathbf{0 . 6 3}$ & $\varnothing=0.58$ \\
B4 & 0.49 & 0.51 & 0.49 & 0.35 & 0.30 & 0.38 & $\mathbf{0 . 5 9}$ & 0.55 & $\mathbf{0 . 6 0}$ \\
B5 & 0.53 & 0.53 & 0.55 & 0.48 & 0.28 & 0.47 & $\mathbf{0 . 6 3}$ & $\mathbf{0 . 6 2}$ \\
B6 & 0.52 & 0.54 & 0.55 & 0.50 & 0.37 & 0.36 & $\mathbf{0 . 6 5}$ & 0.55 \\
B7 & 0.46 & 0.47 & 0.49 & 0.42 & 0.29 & 0.40 & 0.45 & 0.55 \\
B8 & 0.53 & 0.51 & 0.52 & 0.44 & 0.32 & 0.41 & $\mathbf{0 . 6 0}$ & 0.47 \\
\hline
\end{tabular}

Government officials

\begin{tabular}{cccccccccc}
\hline Barrier & B1 & B2 & B3 & B4 & B5 & B6 & B7 & B8 \\
\hline B1 & 0.87 & 0.95 & 0.87 & 0.94 & 0.62 & 0.59 & $\mathbf{1 . 0 0}$ & $\mathbf{1 . 0 5}$ \\
B2 & 0.90 & 0.75 & 0.81 & 0.89 & 0.56 & 0.58 & 0.91 & 0.95 \\
B3 & 0.91 & 0.83 & 0.69 & 0.84 & 0.57 & 0.53 & 0.89 & 0.87 & $\varnothing=0.95$ \\
B4 & 0.84 & 0.81 & 0.73 & 0.70 & 0.52 & 0.51 & 0.86 & 0.88 & $\varnothing$ \\
B5 & $\mathbf{0 . 9 8}$ & 0.91 & 0.88 & 0.92 & 0.56 & 0.64 & $\mathbf{1 . 0 1}$ & $\mathbf{1 . 0 0}$ & 0.85 \\
B6 & 0.83 & 0.77 & 0.74 & 0.81 & 0.61 & 0.46 & 0.83 & 0.90 \\
B7 & 0.91 & 0.83 & 0.79 & 0.82 & 0.58 & 0.55 & 0.78 & 0.90 \\
B8 & $\mathbf{1 . 0 0}$ & 0.89 & 0.88 & 0.93 & 0.63 & 0.57 & $\mathbf{0 . 9 7}$ & 0.87 \\
\hline
\end{tabular}

